\title{
Renewable energy for sustainable development in India: current status, future prospects, challenges, employment, and investment opportunities
}

\author{
Charles Rajesh Kumar. J*id and M. A. Majid
}

\begin{abstract}
The primary objective for deploying renewable energy in India is to advance economic development, improve energy security, improve access to energy, and mitigate climate change. Sustainable development is possible by use of sustainable energy and by ensuring access to affordable, reliable, sustainable, and modern energy for citizens. Strong government support and the increasingly opportune economic situation have pushed India to be one of the top leaders in the world's most attractive renewable energy markets. The government has designed policies, programs, and a liberal environment to attract foreign investments to ramp up the country in the renewable energy market at a rapid rate. It is anticipated that the renewable energy sector can create a large number of domestic jobs over the following years. This paper aims to present significant achievements, prospects, projections, generation of electricity, as well as challenges and investment and employment opportunities due to the development of renewable energy in India. In this review, we have identified the various obstacles faced by the renewable sector. The recommendations based on the review outcomes will provide useful information for policymakers, innovators, project developers, investors, industries, associated stakeholders and departments, researchers, and scientists.
\end{abstract}

Keywords: India, Sustainable, Renewable energy, Achievements, Initiatives, Barriers, Recommendations, Investment, Employment, Developers, Policymakers, Investors

\section{Introduction}

The sources of electricity production such as coal, oil, and natural gas have contributed to one-third of global greenhouse gas emissions. It is essential to raise the standard of living by providing cleaner and more reliable electricity [1]. India has an increasing energy demand to fulfill the economic development plans that are being implemented. The provision of increasing quanta of energy is a vital pre-requisite for the economic growth of a country [2]. The National Electricity Plan [NEP] [3] framed by the Ministry of Power (MoP) has developed a 10 -year detailed action plan with the objective to provide electricity across the country, and has prepared a further plan to ensure that power is supplied to the citizens

\footnotetext{
* Correspondence: ckumar@effatuniversity.edu.sa; charlesece@yahoo.com Department of Electrical and Computer Engineering, College of Engineering, Effat University, Box 34689, Jeddah, PO 21478, Saudi Arabia
}

efficiently and at a reasonable cost. According to the World Resource Institute Report 2017 [4, 5], India is responsible for nearly $6.65 \%$ of total global carbon emissions, ranked fourth next to China (26.83\%), the USA (14.36\%), and the EU (9.66\%). Climate change might also change the ecological balance in the world. Intended Nationally Determined Contributions (INDCs) have been submitted to the United Nations Framework Convention on Climate Change (UNFCCC) and the Paris Agreement. The latter has hoped to achieve the goal of limiting the rise in global temperature to well below $2{ }^{\circ} \mathrm{C}$ $[6,7]$. According to a World Energy Council [8] prediction, global electricity demand will peak in 2030. India is one of the largest coal consumers in the world and imports costly fossil fuel [8]. Close to $74 \%$ of the energy demand is supplied by coal and oil. According to a report from the Center for monitoring Indian economy, the 
country imported 171 million tons of coal in 2013-2014, 215 million tons in 2014-2015, 207 million tons in 2015-2016, 195 million tons in 2016-2017, and 213 million tons in 2017-2018 [9]. Therefore, there is an urgent need to find alternate sources for generating electricity.

In this way, the country will have a rapid and global transition to renewable energy technologies to achieve sustainable growth and avoid catastrophic climate change. Renewable energy sources play a vital role in securing sustainable energy with lower emissions [10]. It is already accepted that renewable energy technologies might significantly cover the electricity demand and reduce emissions. In recent years, the country has developed a sustainable path for its energy supply. Awareness of saving energy has been promoted among citizens to increase the use of solar, wind, biomass, waste, and hydropower energies. It is evident that clean energy is less harmful and often cheaper. India is aiming to attain $175 \mathrm{GW}$ of renewable energy which would consist of $100 \mathrm{GW}$ from solar energy, $10 \mathrm{GW}$ from bio-power, 60 GW from wind power, and 5 GW from small hydropower plants by the year 2022 [11]. Investors have promised to achieve more than $270 \mathrm{GW}$, which is significantly above the ambitious targets. The promises are as follows: $58 \mathrm{GW}$ by foreign companies, $191 \mathrm{GW}$ by private companies, $18 \mathrm{GW}$ by private sectors, and $5 \mathrm{GW}$ by the Indian Railways [12]. Recent estimates show that in 2047, solar potential will be more than $750 \mathrm{GW}$ and wind potential will be $410 \mathrm{GW}[13,14]$. To reach the ambitious targets of generating $175 \mathrm{GW}$ of renewable energy by 2022 , it is essential that the government creates 330,000 new jobs and livelihood opportunities $[15,16]$.

A mixture of push policies and pull mechanisms, accompanied by particular strategies should promote the development of renewable energy technologies. Advancement in technology, proper regulatory policies [17], tax deduction, and attempts in efficiency enhancement due to research and development (R\&D) [18] are some of the pathways to conservation of energy and environment that should guarantee that renewable resource bases are used in a costeffective and quick manner. Hence, strategies to promote investment opportunities in the renewable energy sector along with jobs for the unskilled workers, technicians, and contractors are discussed. This article also manifests technological and financial initiatives [19], policy and regulatory framework, as well as training and educational initiatives $[20,21]$ launched by the government for the growth and development of renewable energy sources. The development of renewable technology has encountered explicit obstacles, and thus, there is a need to discuss these barriers. Additionally, it is also vital to discover possible solutions to overcome these barriers, and hence, proper recommendations have been suggested for the steady growth of renewable power [22-24]. Given the enormous potential of renewables in the country, coherent policy measures and an investor-friendly administration might be the key drivers for India to become a global leader in clean and green energy.

\section{Projection of global primary energy consumption}

An energy source is a necessary element of socioeconomic development. The increasing economic growth of developing nations in the last decades has caused an accelerated increase in energy consumption. This trend is anticipated to grow [25]. A prediction of future power consumption is essential for the investigation of adequate environmental and economic policies [26]. Likewise, an outlook to future power consumption helps to determine future investments in renewable energy. Energy supply and security have not only increased the essential issues for the development of human society but also for their global political and economic patterns [27]. Hence, international comparisons are helpful to identify past, present, and future power consumption.

Table 1 shows the primary energy consumption of the world, based on the BP Energy Outlook 2018 reports. In 2016, India's overall energy consumption was 724 million tons of oil equivalent (Mtoe) and is expected to rise to 1921 Mtoe by 2040 with an average growth rate of $4.2 \%$ per annum. Energy consumption of various major countries comprises commercially traded fuels and modern renewables used to produce power. In 2016, India was the fourth largest energy consumer in the world after China, the USA, and the Organization for economic co-operation and development (OECD) in Europe [29].

The projected estimation of global energy consumption demonstrates that energy consumption in India is continuously increasing and retains its position even in 2035/ 2040 [28]. The increase in India's energy consumption will push the country's share of global energy demand to $11 \%$ by 2040 from 5\% in 2016. Emerging economies such as China, India, or Brazil have experienced a process of rapid industrialization, have increased their share in the global economy, and are exporting enormous volumes of manufactured products to developed countries. This shift of economic activities among nations has also had consequences concerning the country's energy use [30].

\section{Projected primary energy consumption in India}

The size and growth of a country's population significantly affects the demand for energy. With 1.368 billion citizens, India is ranked second, of the most populous countries as of January 2019 [31]. The yearly growth rate is $1.18 \%$ and represents almost $17.74 \%$ of the world's population. The country is expected to have more than 1.383 billion, 1.512 billion, 1.605 billion, 1.658 billion people by the end of 2020, 2030, 2040, and 2050, respectively. Each year, India adds a higher number of 
Table 1 Projected primary energy consumption of the world between 1990 and 2040 [28]

\begin{tabular}{|c|c|c|c|c|c|c|c|c|c|c|c|c|c|}
\hline \multirow[t]{2}{*}{ Region } & \multicolumn{11}{|c|}{ Consumption (million tones oil equivalent) } & \multicolumn{2}{|c|}{ Change (percentage per annum) } \\
\hline & 1990 & 1995 & 2000 & 2005 & 2010 & 2016 & 2020 & 2025 & 2030 & 2035 & 2040 & 1990-2016 & $2016-2040$ \\
\hline United States & 1966 & 2119 & 2310 & 2349 & 2284 & 2273 & 2334 & 2344 & 2341 & 2325 & 2299 & $0.6 \%$ & $0.0 \%$ \\
\hline Brazil & 126 & 158 & 188 & 211 & 268 & 298 & 330 & 378 & 419 & 451 & 477 & $3.4 \%$ & $2.0 \%$ \\
\hline EU & 1672 & 1661 & 1732 & 1819 & 1754 & 1642 & 1667 & 1623 & 1570 & 1513 & 1460 & $-0.1 \%$ & $-0.5 \%$ \\
\hline Russia & 865 & 662 & 620 & 647 & 673 & 674 & 711 & 720 & 723 & 722 & 716 & $-1.0 \%$ & $0.3 \%$ \\
\hline Middle East & 264 & 351 & 423 & 565 & 734 & 895 & 980 & 1085 & 1189 & 1287 & 1382 & $4.8 \%$ & $1.8 \%$ \\
\hline Africa & 222 & 244 & 274 & 327 & 389 & 440 & 509 & 603 & 710 & 840 & 1002 & $2.7 \%$ & $3.5 \%$ \\
\hline China & 683 & 889 & 1008 & 1800 & 2491 & 3053 & 3387 & 3753 & 4017 & 4207 & 4319 & $5.9 \%$ & $1.5 \%$ \\
\hline India & 195 & 251 & 316 & 394 & 537 & 724 & 880 & 1118 & 1365 & 1624 & 1921 & $5.2 \%$ & $4.2 \%$ \\
\hline
\end{tabular}

people to the world than any other nation and the specific population of some of the states in India is equal to the population of many countries.

The growth of India's energy consumption will be the fastest among all significant economies by 2040, with coal meeting most of this demand followed by renewable energy. Renewables became the second most significant source of domestic power production, overtaking gas and then oil, by 2020. The demand for renewables in India will have a tremendous growth of 256 Mtoe in 2040 from 17 Mtoe in 2016, with an annual increase of $12 \%$, as shown in Table 2.

Table 3 shows the primary energy consumption of renewables for the BRIC countries (Brazil, Russia, India, and China) from 2016 to 2040. India consumed around 17 Mtoe of renewable energy in 2016, and this will be 256 Mtoe in 2040. It is probable that India's energy consumption will grow fastest among all major economies by 2040 , with coal contributing most in meeting this demand followed by renewables. The percentage share of renewable consumption in 2016 was $2 \%$ and is predicted to increase by $13 \%$ by 2040 .

\section{How renewable energy sources contribute to the energy demand in India}

Even though India has achieved a fast and remarkable economic growth, energy is still scarce. Strong economic growth in India is escalating the demand for energy, and more energy sources are required to cover this demand. At the same time, due to the increasing population and environmental deterioration, the country faces the challenge of sustainable development. The gap between demand and supply of power is expected to rise in the future [32]. Table 4 presents the power supply status of the country from 2009-2010 to 2018-2019 (until October 2018). In 2018, the energy demand was 1,212, $134 \mathrm{GWh}$, and the availability was $1,203,567 \mathrm{GWh}$, i.e., a deficit of $-0.7 \%$ [33].

According to the Load generation and Balance Report (2016-2017) of the Central Electricity Authority of India (CEA), the electrical energy demand for 2021-2022 is anticipated to be at least 1915 terawatt hours (TWh), with a peak electric demand of $298 \mathrm{GW}$ [34]. Increasing urbanization and rising income levels are responsible for an increased demand for electrical appliances, i.e., an increased demand for electricity in the residential sector. The increased demand in materials for buildings, transportation, capital goods, and infrastructure is driving the industrial demand for electricity. An increased mechanization and the shift to groundwater irrigation across the country is pushing the pumping and tractor demand in the agriculture sector, and hence the large diesel and electricity demand. The penetration of electric vehicles and the fuel switch to electric and induction cook

Table 2 Projected primary energy consumption of India (including renewable energy) from 2016 to 2040 [28]

\begin{tabular}{|c|c|c|c|c|c|c|c|c|c|c|c|c|c|}
\hline & \multicolumn{13}{|c|}{ Level (Mtoe) } \\
\hline & 1990 & 1995 & 2000 & 2005 & 2010 & 2016 & 2020 & 2025 & 2030 & 2035 & 2040 & 1990-2016 & 2016-2040 \\
\hline Total & 195 & 251 & 316 & 394 & 537 & 724 & 880 & 1118 & 1365 & 1624 & 1921 & $5.2 \%$ & $4.2 \%$ \\
\hline Oil (Mb/dl) & 58 & 75 & 106 & 122 & 155 & 212 & 251 & 308 & 359 & 419 & 485 & $5.1 \%$ & $3.5 \%$ \\
\hline Gas (Bcf/dl) & 11 & 17 & 24 & 32 & 54 & 45 & 57 & 72 & 89 & 106 & 128 & $5.6 \%$ & $4.5 \%$ \\
\hline Coal & 110 & 140 & 164 & 211 & 290 & 412 & 485 & 593 & 710 & 824 & 955 & $5.2 \%$ & $3.6 \%$ \\
\hline Nuclear & 1 & 2 & 4 & 4 & 5 & 9 & 11 & 16 & 27 & 35 & 44 & $7.1 \%$ & $7.0 \%$ \\
\hline Hydro & 15 & 17 & 17 & 22 & 25 & 29 & 36 & 43 & 47 & 50 & 52 & $2.6 \%$ & $2.5 \%$ \\
\hline Renewables & 0 & 0 & 1 & 2 & 7 & 17 & 41 & 86 & 133 & 191 & 256 & $35.1 \%$ & $12.0 \%$ \\
\hline
\end{tabular}


Table 3 Renewable energy consumption-BRIC countries (percentage): 2015-2035: source: BP Energy Outlook 2017 [28]

\begin{tabular}{|c|c|c|c|c|c|c|c|c|c|c|}
\hline \multirow[t]{2}{*}{ Between 2016 and 2040} & \multicolumn{2}{|l|}{ India } & \multicolumn{2}{|c|}{ China } & \multicolumn{2}{|c|}{ United States } & \multicolumn{2}{|c|}{ Russia } & \multicolumn{2}{|l|}{ Brazil } \\
\hline & 2016 & 2040 & 2016 & 2040 & 2016 & 2040 & 2016 & 2040 & 2016 & 2040 \\
\hline Primary energy consumption renewables (including biofuels) & $2 \%$ & $13 \%$ & $3 \%$ & $18 \%$ & $5 \%$ & $17 \%$ & $0 \%$ & $2 \%$ & $13 \%$ & $24 \%$ \\
\hline
\end{tabular}

stoves will drive the electricity demand in the other sectors shown in Table 5 .

According to the International Renewable Energy Agency (IRENA), a quarter of India's energy demand can be met with renewable energy. The country could potentially increase its share of renewable power generation to over one-third by 2030 [35].

Table 6 presents the estimated contribution of renewable energy sources to the total energy demand. MoP along with CEA in its draft national electricity plan for 2016 anticipated that with $175 \mathrm{GW}$ of installed capacity of renewable power by 2022, the expected electricity generation would be 327 billion units (BUs), which would contribute to $1611 \mathrm{BU}$ energy requirements. This indicates that $20.3 \%$ of the energy requirements would be fulfilled by renewable energy by 2022 and $24.2 \%$ by 2027 [36]. Figure 1 shows the ambitious new target for the share of renewable energy in India's electricity consumption set by MoP. As per the order of revised RPO (Renewable Purchase Obligations, legal act of June 2018), the country has a target of a $21 \%$ share of renewable energy in its total electricity consumption by March 2022. In 2014, the same goal was at $15 \%$ and increased to $21 \%$ by 2018 . It is India's goal to reach $40 \%$ renewable sources by 2030 .

\section{Estimated renewable energy potential in India}

The estimated potential of wind power in the country during 1995 [37] was found to be 20,000 MW (20 GW), solar energy was $5 \times 10^{15} \mathrm{kWh} / \mathrm{pa}$, bioenergy was 17,000
MW, bagasse cogeneration was $8000 \mathrm{MW}$, and small hydropower was 10,000 MW. For 2006, the renewable potential was estimated as $85,000 \mathrm{MW}$ with wind 4500 MW, solar $35 \mathrm{MW}$, biomass/bioenergy 25,000 MW, and small hydropower of 15,000 MW [38]. According to the annual report of the Ministry of New and Renewable Energy (MNRE) for 2017-2018, the estimated potential of wind power was $302.251 \mathrm{GW}$ (at 100-m mast height), of small hydropower $19.749 \mathrm{GW}$, biomass power 17.536 GW, bagasse cogeneration $5 \mathrm{GW}$, waste to energy (WTE) $2.554 \mathrm{GW}$, and solar $748.990 \mathrm{GW}$. The estimated total renewable potential amounted to $1096.080 \mathrm{GW}$ [39] assuming 3\% wasteland, which is shown in Table 7. India is a tropical country and receives significant radiation, and hence the solar potential is very high [40-42].

\section{Gross installed capacity of renewable energy in India}

As of June 2018 reports, the country intends to reach $225 \mathrm{GW}$ of renewable power capacity by 2022 exceeding the target of $175 \mathrm{GW}$ pledged during the Paris Agreement. The sector is the fourth most attractive renewable energy market in the world. As in October 2018, India ranked fifth in installed renewable energy capacity [43].

\section{Gross installed capacity of renewable energy-according to region}

Table 8 lists the cumulative installed capacity of both conventional and renewable energy sources. The cumulative installed capacity of renewable sources as on the

Table 4 The power supply status in the country from 2009-2010 to 2017-2018 [33]

\begin{tabular}{|c|c|c|c|c|c|c|c|c|}
\hline \multirow[t]{3}{*}{ Year } & \multicolumn{4}{|l|}{ Energy } & \multicolumn{4}{|l|}{ Peak } \\
\hline & \multirow{2}{*}{$\begin{array}{l}\text { Requirement } \\
\text { (GWh) }\end{array}$} & \multirow{2}{*}{$\begin{array}{l}\text { Availability } \\
\text { GWh) }\end{array}$} & \multicolumn{2}{|c|}{ Surplus(+)/Deficits(-) } & \multirow{2}{*}{$\begin{array}{l}\text { Peak Demand } \\
(\mathrm{MW})\end{array}$} & \multirow{2}{*}{$\begin{array}{l}\text { Peak Met } \\
(\mathrm{MW})\end{array}$} & \multicolumn{2}{|c|}{ Surplus(+)/Deficits(-) } \\
\hline & & & $(\mathrm{GWh})$ & $(\%)$ & & & $(\mathrm{MW})$ & (\%) \\
\hline $2009-2010$ & 830,594 & 746,644 & $-83,950$ & -10.11 & 119,166 & 104009 & $-15,157$ & -12.72 \\
\hline 2010-2011 & 861,591 & 788,355 & $-73,236$ & -8.50 & 122,287 & 110256 & $-12,031$ & -9.84 \\
\hline 2011-2012 & 937,199 & 857,886 & $-79,313$ & -8.46 & 130,006 & 116,191 & $-13,815$ & -10.63 \\
\hline 2012-2013 & 998,114 & 911,209 & $-86,905$ & -8.71 & 135,453 & 123,294 & $-12,159$ & -8.98 \\
\hline 2013-2014 & $1,002,257$ & 959,829 & $-42,428$ & -4.23 & 135,918 & 129,815 & -6103 & -4.49 \\
\hline 2014-2015 & $1,067,085$ & $1,028,955$ & $-38,130$ & -3.60 & 148,166 & 141,160 & -7006 & -4.70 \\
\hline 2015-2016 & $1,114,408$ & $1,090,850$ & $-23,558$ & -2.10 & 153,366 & 148,463 & -4903 & -3.20 \\
\hline 2016-2017 & $1,142,928$ & $1,135,332$ & -7596 & -0.66 & 159,542 & 156,934 & -2608 & -1.63 \\
\hline 2017-2018 & $1,212,134$ & $1,203,567$ & -8.567 & -0.7 & 164,066 & 160,752 & -3314 & -2.0 \\
\hline 2018-2019 (31.10.2018) & 769,399 & 764,627 & -4773 & -0.6 & 177,022 & 175,528 & -1494 & -0.8 \\
\hline
\end{tabular}


Table 5 Electricity demand in different demand sectors [35]

\begin{tabular}{lllll}
\hline TWh & 2012 & 2022 & 2030 & 2047 \\
\hline Industry & 336 & 494 & 703 & 1366 \\
Residential & 175 & 480 & 842 & 1840 \\
Commercial & 86 & 142 & 238 & 771 \\
Agriculture & 136 & 245 & 336 & 501 \\
Others & 29 & 71 & 121 & 233 \\
Total & 762 & 1433 & 2239 & 4712 \\
\hline
\end{tabular}

$31^{\text {st }}$ of December 2018 was 74081.66 MW. Renewable energy (small hydropower, wind, biomass, WTE, solar) accounted for an approximate $21 \%$ share of the cumulative installed power capacity, and the remaining $78.791 \%$ originated from other conventional sources (coal, gas diesel, nuclear, and large hydropower) [44]. The best regions for renewable energy are the southern states that have the highest solar irradiance and wind in the country. When renewable energy alone is considered for analysis, the Southern region covers $49.121 \%$ of the cumulative installed renewable capacity, followed by the Western region (29.742\%), the Northern region (18.890\%), the Eastern region (1.836\%), the North-Easter region $0.394 \%$, and the Islands $(0.017 \%)$. As far as conventional energy is concerned, the Western region with $33.452 \%$ ranks first and is followed by the Northern region with $28.484 \%$, the Southern region $(24.967 \%)$, the Eastern region $(11.716 \%)$, the Northern-Eastern $(1.366 \%)$, and the Islands $(0.015 \%)$.

\section{Gross installed capacity of renewable energy-according to ownership}

State government, central government, and private players drive the Indian energy sector. The private sector leads the way in renewable energy investment. Table 9 shows the installed gross renewable energy and conventional energy capacity (percentage)-ownership wise. It is evident from Fig. 2 that $95 \%$ of the installed renewable capacity derives from private companies, $2 \%$ from the central government, and $3 \%$ from the state government. The top private companies in the field of non-conventional energy generation are Tata Power Solar, Suzlon, and ReNew Power. Tata Power Solar System Limited are the most significant integrated solar power players in the country, Suzlon realizes wind energy projects, and ReNew Power Ventures operate with solar and wind power.
Gross installed capacity of renewable energy-state wise Table 10 shows the installed capacity of cumulative renewable energy (state wise), out of the total installed capacity of 74,081.66 MW, where Karnataka ranks first with 12,953.24 MW (17.485\%), Tamilnadu second with 11,934.38 MW (16\%), Maharashtra third with 9283.78 MW (12.532\%), Gujarat fourth with 10.641 MW (10.641\%), and Rajasthan fifth with 7573.86 MW (10.224\%). These five states cover almost $66.991 \%$ of the installed capacity of total renewable. Other prominent states are Andhra Pradesh (9.829\%), Madhya Pradesh (5.819\%), Telangana (5.137\%), and Uttar Pradesh (3.879\%). These nine states cover almost $91.655 \%$.

\section{Gross installed capacity of renewable energy-according to source}

Under union budget of India 2018-2019, INR 3762 crore (USD 581.09 million), was allotted for gridinteractive renewable power schemes and projects. As per the 31.12.2018, the installed capacity of total renewable power (excluding large hydropower) in the country amounted to $74.08166 \mathrm{GW}$. Around $9.363 \mathrm{GW}$ of solar energy, $1.766 \mathrm{GW}$ of wind, $0.105 \mathrm{GW}$ of small hydropower (SHP), and biomass power of $8.7 \mathrm{GW}$ capacity were added in 2017-2018. Table 11 shows the installed capacity of renewable energy over the last 10 years until the 31.12.2018. Wind energy continues to dominate the countries renewable energy industry, accounting for over $47 \%$ of cumulative installed renewable capacity (35, 138.15 MW), followed by solar power of $34 \%(25,212.26$ MW), biomass power/cogeneration of $12 \% \quad(9075.5$ $\mathrm{MW}$ ), and small hydropower of 6\% (4517.45 MW). In the renewable energy country attractiveness index (RECAI) of 2018, India ranked in fourth position. The installed renewable energy production capacity has grown at an accelerated pace over the preceding few years, posting a CAGR of $19.78 \%$ between 2014 and 2018 [45].

\section{Estimation of the installed capacity of renewable energy Table 12 gives the share of installed cumulative renew- able energy capacity, in comparison with the installed conventional energy capacity. In 2022 and 2032, the in- stalled renewable energy capacity will account for $32 \%$ and $35 \%$, respectively $[46,47]$. The most significant re- newable capacity expansion program in the world is}

Table 6 Estimated contribution of renewable energy sources to the total energy demand [35]

\begin{tabular}{|c|c|c|c|c|c|c|c|c|}
\hline \multirow[t]{2}{*}{ Year } & \multirow{2}{*}{$\begin{array}{l}\text { Installed capacity } \\
\text { of renewable } \\
\text { energy Sources } \\
\text { (GW) }\end{array}$} & \multicolumn{5}{|c|}{ Expected Generation (Billion Unit) } & \multirow{2}{*}{$\begin{array}{l}\text { Total energy } \\
\text { requirement } \\
\text { (Billion Unit) }\end{array}$} & \multirow{2}{*}{$\begin{array}{l}\% \text { The } \\
\text { Contribution of } \\
\text { renewable energy } \\
\text { source }\end{array}$} \\
\hline & & Solar & Wind & Biomass & Small hydropower & Total & & \\
\hline $2021-22$ & 175 & 162 & 122 & 38 & 15 & 327 & 1611 & 20.3 \\
\hline $2026-27$ & 275 & 243 & 188 & 64 & 21 & 516 & 2132 & 24.2 \\
\hline
\end{tabular}




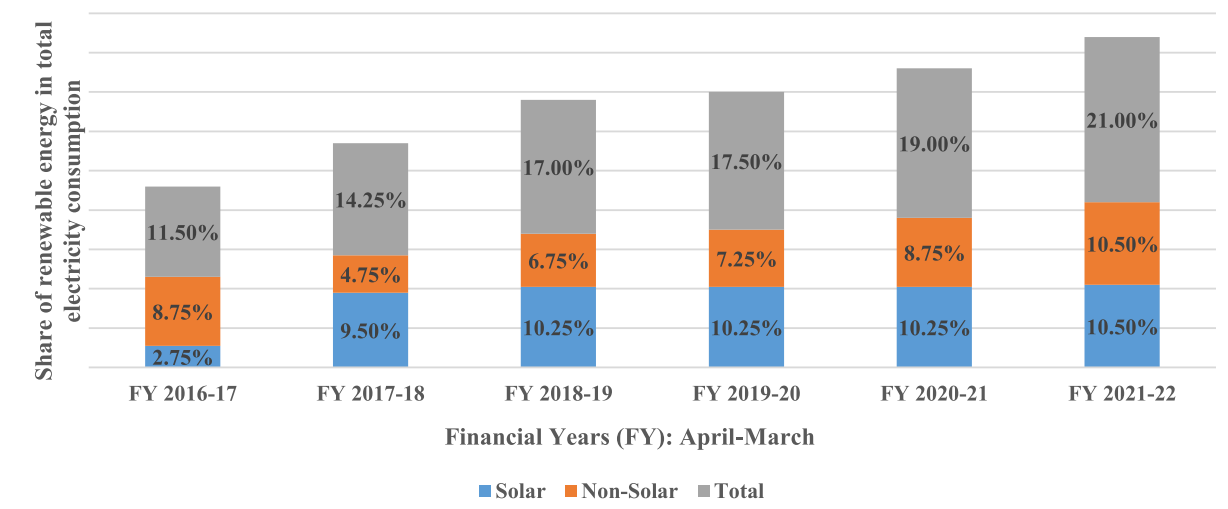

Fig. 1 Target share of renewable energy in India's power consumption

being taken up by India. The government is preparing to boost the percentage of clean energy through a tremendous push in renewables, as discussed in the subsequent sections.

\section{Gross electricity generation from renewable energy in India}

The overall generation (including the generation from grid-connected renewable sources) in the country has grown exponentially. Between 2014-2015 and 2015-2016, it achieved 1110.458 BU and $1173.603 \mathrm{BU}$, respectively. The same was recorded with 1241.689 BU and 1306.614 BU during 2015-2016 and 1306.614 BU from 2016-2017 and 2017-2018, respectively. Figure 3 indicates that the annual renewable power production increased faster than the conventional power production. The rise accounted for $6.47 \%$ in $2015-2016$ and $24.88 \%$ in $2017-2018$, respectively. Table 13 compares the energy generation from traditional sources with that from renewable sources. Remarkably, the energy generation from conventional sources reached 811.143 BU and from renewable sources 9.860 BU in 2010 compared to 1.206.306 BU and 88.945 BU in 2017, respectively [48]. It is observed that the price of electricity production using renewable technologies is higher than that for conventional generation technologies, but is likely to fall with increasing experience in the techniques involved [49].

\section{Gross electricity generation from renewable energy-according to regions}

Table 14 shows the gross electricity generation from renewable energy-region wise. It is noted that the highest renewable energy generation derives from the southern region, followed by the western part. As of November $2018,50.33 \%$ of energy generation was obtained from the southern area and $29.37 \%, 18.05 \%, 2 \%$, and $0.24 \%$ from Western, Northern, North-Eastern Areas, and the Island, respectively.

\section{Gross electricity generation from renewable energy-according to states}

Table 15 shows the gross electricity generation from renewable energy-region-wise. It is observed that the highest renewable energy generation was achieved from Karnataka (16.57\%), Tamilnadu (15.82\%), Andhra Pradesh (11.92\%), and Gujarat (10.87\%) as per November 2018. While adding four years from 2015-2016 to 2018-2019 Tamilnadu [50] remains in the first position followed by Karnataka, Maharashtra, Gujarat and Andhra Pradesh.

\section{Gross electricity generation from renewable energy-according to sources}

Table 16 shows the gross electricity generation from renewable energy-source-wise. It can be concluded from the table that the wind-based energy generation as per 2017-2018 is most prominent with $51.71 \%$, followed by solar energy $(25.40 \%)$, Bagasse (11.63\%), small hydropower (7.55\%), biomass (3.34\%), and WTE (0.35\%). There has been a constant increase in the generation of all renewable sources from 2014-2015 to date. Wind energy, as always, was the highest contributor to the total renewable power production. The percentage of solar energy produced in the overall renewable power production comes next to wind and is typically reduced during the monsoon months. The definite improvement in wind energy production can be associated with a "good" monsoon. Cyclonic action during these months also facilitates high-speed winds. Monsoon winds play a significant part in the uptick in wind power production, especially in the southern states of the country.

\section{Estimation of gross electricity generation from renewable energy}

Table 17 shows an estimation of gross electricity generation from renewable energy based on the 2015 report of the National Institution for Transforming India (NITI Aayog) [51]. It is predicted that the share of renewable 
Table 7 The estimated renewable potential in India [40]

\begin{tabular}{|c|c|c|c|c|c|c|c|c|}
\hline \multicolumn{9}{|c|}{ State-wise Renewable Energy Potential (in MW) } \\
\hline \multirow[t]{2}{*}{ SI. No. } & \multirow[t]{2}{*}{ States/UTs } & \multirow{2}{*}{$\begin{array}{l}\text { Wind power } \\
\text { (MW) }\end{array}$} & \multirow{2}{*}{$\begin{array}{l}\text { Small hydro } \\
\text { power }\end{array}$} & \multicolumn{3}{|l|}{ Bio-energy } & \multirow[t]{2}{*}{ Solar } & \multirow[t]{2}{*}{ Total } \\
\hline & & & & Biomass power & Bagasse cogeneration & Waste to energy & & \\
\hline 1 & Andhra Pradesh & 44.229 & 0.978 & 0.578 & 0.3 & 0.123 & 38.44 & 84.648 \\
\hline 2 & Arunachal Pradesh & 0 & 1.341 & 0.008 & 0 & 0 & 8.65 & 9.999 \\
\hline 3 & Assam & 0 & 0.239 & 0.212 & 0 & 0.008 & 13.76 & 14.219 \\
\hline 4 & Bihar & 0 & 0.223 & 0.619 & 0.3 & 0.073 & 11.2 & 12.415 \\
\hline 5 & Chhattisgarh & 0.077 & 1.107 & 0.236 & 0 & 0.024 & 18.27 & 19.714 \\
\hline 6 & Goa & 0.001 & 0.007 & 0.026 & 0 & 0 & 0.88 & 0.914 \\
\hline 7 & Gujarat & 84.431 & 0.202 & 1.221 & 0.35 & 0.112 & 35.77 & 122.086 \\
\hline 8 & Haryana & 0 & 0.11 & 1.333 & 0.35 & 0.024 & 4.56 & 6.377 \\
\hline 9 & Himachal Pradesh & 0 & 2.398 & 0.142 & 0 & 0.002 & 33.84 & 36.382 \\
\hline 10 & Jammu \& Kashmir & 0 & 1.431 & 0.043 & 0 & 0 & 111.05 & 112.524 \\
\hline 11 & Jharkhand & 0 & 0.209 & 0.09 & 0 & 0.01 & 18.18 & 18.489 \\
\hline 12 & Karnataka & 55.857 & 4.141 & 1.131 & 0.45 & 0 & 24.7 & 86.279 \\
\hline 13 & Kerala & 1.7 & 0.704 & 1.044 & 0 & 0.036 & 6.11 & 9.594 \\
\hline 14 & Madhya Pradesh & 10.484 & 0.82 & 1.364 & 0 & 0.078 & 61.66 & 74.406 \\
\hline 15 & Maharashtra & 45.394 & 0.794 & 1.887 & 1.25 & 0.287 & 64.32 & 113.932 \\
\hline 16 & Manipur & 0 & 0.109 & 0.013 & 0 & 0.002 & 10.63 & 10.754 \\
\hline 17 & Meghalaya & 0 & 0.23 & 0.011 & 0 & 0.002 & 5.86 & 6.103 \\
\hline 18 & Mizoram & 0 & 0.169 & 0.001 & 0 & 0.002 & 9.09 & 9.262 \\
\hline 19 & Nagaland & 0 & 0.197 & 0.01 & 0 & 0 & 7.29 & 7.497 \\
\hline 20 & Odisha & 3.093 & 0.295 & 0.246 & 0 & 0.022 & 25.78 & 29.436 \\
\hline 21 & Punjab & 0 & 0.441 & 3.172 & 0.3 & 0.045 & 2.81 & 6.768 \\
\hline 22 & Rajasthan & 18.77 & 0.057 & 1.039 & 0 & 0.062 & 142.31 & 162.238 \\
\hline 23 & Sikkim & 0 & 0.267 & 0.002 & 0 & 0 & 4.94 & 5.209 \\
\hline 24 & Tamil Nadu & 33.8 & 0.66 & 1.07 & 0.45 & 0.151 & 17.67 & 53.801 \\
\hline 25 & Telangana & 4.244 & 0 & 0 & 0 & 0 & 20.41 & 24.654 \\
\hline 26 & Tripura & 0 & 0.047 & 0.003 & 0 & 0.002 & 2.08 & 2.132 \\
\hline 27 & Uttar Pradesh & 0 & 0.461 & 1.617 & 1.25 & 0.176 & 22.83 & 26.334 \\
\hline 28 & Uttarakhand & 0 & 1.708 & 0.024 & 0 & 0.005 & 16.8 & 18.537 \\
\hline 29 & West Bengal & 0.002 & 0.396 & 0.396 & 0 & 0.148 & 6.26 & 7.202 \\
\hline 30 & Andaman \& Nicobar & 0.008 & 0.008 & 0 & 0 & 0 & 0 & 0.016 \\
\hline 31 & Chandigarh & 0 & 0 & 0 & 0 & 0.006 & 0 & 0.006 \\
\hline 32 & Dadra \& Nagar Haveli & 0 & 0 & 0 & 0 & 0 & 0 & 0 \\
\hline 33 & Daman \& Diu & 0 & 0 & 0 & 0 & 0 & 0 & 0 \\
\hline 34 & Delhi & 0 & 0 & 0 & 0 & 0.131 & 2.05 & 2.181 \\
\hline 35 & Lakshadweep & 0.008 & 0 & 0 & 0 & 0 & 0 & 0.008 \\
\hline 36 & Puducherry & 0.153 & 0 & 0 & 0 & 0.003 & 0 & 0.156 \\
\hline \multirow[t]{2}{*}{37} & Others & 0 & 0 & 0 & 0 & 1.022 & 0.79 & 1.812 \\
\hline & Total & 302.251 & 19.749 & 17.536 & 5 & 2.554 & 748.99 & 1096.08 \\
\hline
\end{tabular}

power will be $10.2 \%$ by 2022 , but renewable power technologies contributed a record of $13.4 \%$ to the cumulative power production in India as of the 31st of August 2018. The power ministry report shows that India generated
122.10 TWh and out of the total electricity produced, renewables generated $16.30 \mathrm{TWh}$ as on the 31st of August 2018. According to the India Brand Equity Foundation report, it is anticipated that by the year 2040, 
Table 8 All India installed capacity (MW) of power stations as on the 31st of December 2018

\begin{tabular}{|c|c|c|c|c|c|c|c|c|}
\hline \multirow[t]{3}{*}{ Region } & \multicolumn{7}{|c|}{ Mode-wise breakup } & \multirow[t]{3}{*}{ Total } \\
\hline & \multicolumn{4}{|l|}{ Thermal } & \multirow[t]{2}{*}{ Nuclear } & \multirow[t]{2}{*}{ Hydro } & \multirow[t]{2}{*}{$\overline{\text { Renewable }}$} & \\
\hline & Coal & Lignite & Gas & $\overline{\text { Diesel }}$ & & & & \\
\hline Northern & 49700.20 & 1580.00 & 5781.26 & 0 & 1620.00 & $19,707.77$ & $13,994.37$ & 92383.60 \\
\hline Western & $70,328.62$ & 1540.00 & $10,806.49$ & 0 & 1840.00 & 7547.50 & $22,033.01$ & $114,095.62$ \\
\hline Southern & $43,342.02$ & 3240.00 & 6473.66 & 561.58 & 3320.00 & $11,774.83$ & $36,389.87$ & $105,101.96$ \\
\hline Eastern & $27,201.64$ & 0 & 100.00 & 0 & 0 & 4942.12 & 1359.98 & $33,603.74$ \\
\hline North-Eastern & 520.02 & 0 & 1775.81 & 36.00 & 0 & 1427.00 & 291.87 & 4050.70 \\
\hline Islands & 0 & 0 & 0 & 40.05 & 0 & 0 & 12.56 & 52.61 \\
\hline All India & $191,092.50$ & 6360.00 & $24,937.22$ & 637.63 & 6780.00 & 45399.22 & $74,081.66$ & $349,288.22$ \\
\hline
\end{tabular}

around $49 \%$ of total electricity will be produced using renewable energy.

\section{Current achievements in renewable energy 2017- 2018}

India cares for the planet and has taken a groundbreaking journey in renewable energy through the last 4 years $[52,53]$. A dedicated ministry along with financial and technical institutions have helped India in the promotion of renewable energy and diversification of its energy mix. The country is engaged in expanding the use of clean energy sources and has already undertaken several large-scale sustainable energy projects to ensure a massive growth of green energy.

1. India doubled its renewable power capacity in the last 4 years. The cumulative renewable power capacity in 2013-2014 reached 35,500 MW and rose to 70,000 MW in 2017-2018.
2. India stands in the fourth and sixth position regarding the cumulative installed capacity in the wind and solar sector, respectively. Furthermore, its cumulative installed renewable capacity stands in fifth position globally as of the 31st of December 2018 .

3. As said above, the cumulative renewable energy capacity target for 2022 is given as 175 GW. For 20172018 , the cumulative installed capacity amounted to 70 $\mathrm{GW}$, the capacity under implementation is $15 \mathrm{GW}$ and the tendered capacity was $25 \mathrm{GW}$. The target, the installed capacity, the capacity under implementation, and the tendered capacity are shown in Fig. 4.

4. There is tremendous growth in solar power. The cumulative installed solar capacity increased by more than eight times in the last 4 years from 2.630 GW (20132014) to 22 GW (2017-2018). As of the 31st of December 2018, the installed capacity amounted to 25.2122 GW.

5. The renewable electricity generated in $2017-2018$ was 101839 BUs.

Table 9 Installed gross renewable energy and conventional energy capacity (percentage)—Ownership wise as per the 31.12 .2018 [43]

\begin{tabular}{llllll}
\hline Region & Energy & State Government & Private & Central Government & Total \\
\hline Northern & Renewable (MW) & 689.56 & 12975.81 & 329 & 689.56 \\
& Conventional (MW) & $27,510.75$ & $25,832.83$ & $25,045.65$ & $27,510.75$ \\
Western & Renewable (MW) & 317.69 & $21,054.03$ & 661.3 & 317.69 \\
& Conventional (MW) & $30,236.32$ & $40,042.67$ & $21,783.62$ & $30,236.32$ \\
Southern & Renewable (MW) & 521.02 & $35,376.95$ & 491.9 & 521.02 \\
& Conventional (MW) & $33,087.19$ & $17,720.3$ & $17,904.6$ & $33,087.19$ \\
Eastern & Renewable (MW) & 225.11 & 1124.87 & 10 & 225.11 \\
& Conventional (MW) & $10,587.92$ & 6774 & $14,881.84$ & $10,587.92$ \\
North-Eastern & Renewable (MW) & 231.74 & 30.13 & 30 & 231.74 \\
& Conventional (MW) & 955.71 & 24.5 & 2778.62 & 955.71 \\
Islands & Renewable (MW) & 5.25 & 2.21 & 5.1 & 5.25 \\
& Conventional (MW) & 40.05 & 0 & 0 & 40.05 \\
All India & Renewable (MW) & 1990.37 & 70564 & 1527.3 & 1990.37 \\
& Conventional (MW) & $102,417.93$ & $90,394.29$ & $82,394.33$ & $102,417.93$ \\
\hline
\end{tabular}




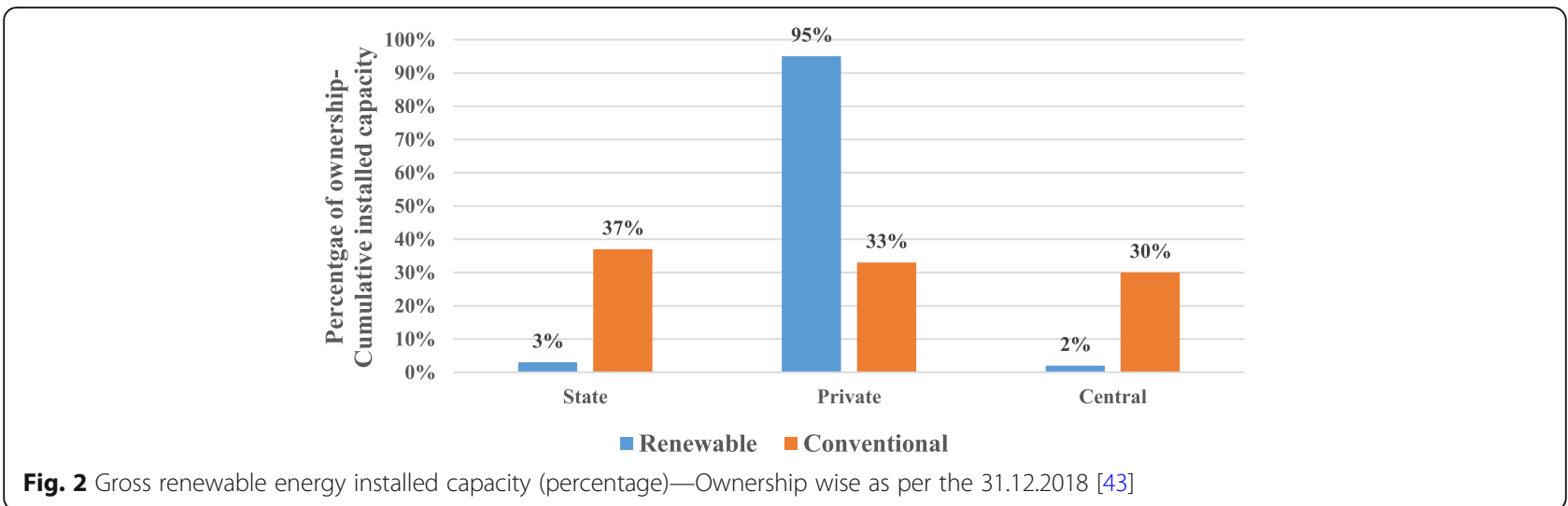

6. The country published competitive bidding guidelines for the production of renewable power. It also discovered the lowest tariff and transparent bidding method and resulted in a notable decrease in per unit cost of renewable energy.

7. In 21 states, there are 41 solar parks with a cumulative capacity of more than 26,144 MW that have already been approved by the MNRE. The Kurnool solar park was set up with $1000 \mathrm{MW}$; and with $2000 \mathrm{MW}$ the largest solar park of Pavagada (Karnataka) is currently under installation.

8. The target for solar power (ground mounted) for 2018-2019 is given as $10 \mathrm{GW}$, and solar power (Rooftop) as $1 \mathrm{GW}$.

9. MNRE doubled the target for solar parks (projects of $500 \mathrm{MW}$ or more) from 20 to $40 \mathrm{GW}$.

10. The cumulative installed capacity of wind power increased by 1.6 times in the last 4 years. In 2013-2014, it amounted to $21 \mathrm{GW}$, from 2017 to 2018 it amounted to $34 \mathrm{GW}$, and as of 31st of December 2018, it reached 35.138 GW. This shows that achievements were completed in wind power use.

11. An offshore wind policy was announced. Thirtyfour companies (most significant global and domestic wind power players) competed in the "expression of interest" (EoI) floated on the plan to set up India's first mega offshore wind farm with a capacity of $1 \mathrm{GW}$.

12. $682 \mathrm{MW}$ small hydropower projects were installed during the last 4 years along with 600 watermills (mechanical applications) and 132 projects still under development.

13. MNRE is implementing green energy corridors to expand the transmission system. $9400 \mathrm{~km}$ of green energy corridors are completed or under implementation. The cost spent on it was INR 10141 crore (101,410 Million INR $=1425.01$ USD). Furthermore, the total capacity of 19,000 MVA substations is now planned to be complete by March 2020.

14. MNRE is setting up solar pumps (off-grid application), where $90 \%$ of pumps have been set up as of today and between 2014-2015 and 2017-2018. Solar street lights were more than doubled. Solar home lighting systems have been improved by around 1.5 times. More than 2,575,000 solar lamps have been distributed to students. The details are illustrated in Fig. 5.

15. From 2014-2015 to 2017-2018, more than 2.5 lakh ( 0.25 million) biogas plants were set up for cooking in rural homes to enable families by providing them access to clean fuel.

16. New policy initiatives revised the tariff policy mandating purchase and generation obligations (RPO and RGO). Four wind and solar inter-state transmission were waived; charges were planned, the RPO trajectory for 2022 and renewable energy policy was finalized.

17. Expressions of interest (EoI) were invited for installing solar photovoltaic manufacturing capacities associated with the guaranteed off-take of $20 \mathrm{GW}$. EoI indicated $10 \mathrm{GW}$ floating solar energy plants.

18. Policy for the solar-wind hybrid was announced. Tender for setting up $2 \mathrm{GW}$ solar-wind hybrid systems in existing projects was invited.

19. To facilitate $R \& D$ in renewable power technology, a National lab policy on testing, standardization, and certification was announced by the MNRE.

20. The Surya Mitra program was conducted to train college graduates in the installation, commissioning, operations, and management of solar panels. The International Solar Alliance (ISA) headquarters in India (Gurgaon) will be a new commencement for solar energy improvement in India.

21. The renewable sector has become considerably more attractive for foreign and domestic investors, and the country expects to attract up to USD 80 billion in the next 4 years from 2018-2019 to 2021-2022.

22 . The solar power capacity expanded by more than eight times from $2.63 \mathrm{GW}$ in $2013-2014$ to $22 \mathrm{GW}$ in 2017-2018.

23. A bidding for $115 \mathrm{GW}$ renewable energy projects up to March 2020 was announced. 
Table 10 Cumulative renewable energy installed capacity—state wise as of 31.12.2018 [43]

\begin{tabular}{|c|c|}
\hline States in India & Cumulative renewable installed capacity (MW) \\
\hline Delhi & 176.21 \\
\hline Haryana & 411.99 \\
\hline Himachal Pradesh & 864.5 \\
\hline Jammu \& Kashmir & 188.88 \\
\hline Punjab & 1282.42 \\
\hline Rajasthan & 7573.86 \\
\hline Uttar Pradesh & 2873.61 \\
\hline Uttarakhand & 590.5 \\
\hline Chandigarh & 32.4 \\
\hline Goa & 1.74 \\
\hline Daman \& Diu & 13.38 \\
\hline Gujarat & 7882.85 \\
\hline Madhya Pradesh & 4310.45 \\
\hline Chhattisgarh & 535.35 \\
\hline Maharashtra & 9283.78 \\
\hline Dadra \& Nagar Navali & 5.46 \\
\hline Andhra Pradesh & 7281.68 \\
\hline Telangana & 3805.83 \\
\hline Karnataka & $12,953.24$ \\
\hline Kerala & 413.01 \\
\hline Tamilnadu & $11,934.38$ \\
\hline Puducherry & 1.73 \\
\hline Bihar & 326.15 \\
\hline Jharkhand & 36.46 \\
\hline West Bengal & 440.82 \\
\hline Odisha & 504.43 \\
\hline Sikkim & 52.12 \\
\hline Assam & 50.79 \\
\hline Arunachal Pradesh & 112.49 \\
\hline Meghalaya & 31.11 \\
\hline Tripura & 21.1 \\
\hline Manipur & 8.04 \\
\hline Nagaland & 31.67 \\
\hline Mizoram & 36.67 \\
\hline Andaman \& Nicobar & 11.81 \\
\hline Lakshadweep & 0.76 \\
\hline Total & $74,081.66$ \\
\hline
\end{tabular}

24. The Bureau of Indian Standards (BIS) acting for system/components of solar PV was established.

25 . To recognize and encourage innovative ideas in renewable energy sectors, the Government provides prizes and awards. Creative ideas/concepts should lead to prototype development. The Name of the award is "Abhinav Soch-Nayi Sambhawanaye," which means Innovative ideas-New possibilities.

\section{Solar energy}

Under the National Solar Mission, the MNRE has updated the objective of grid-connected solar power projects from $20 \mathrm{GW}$ by the year $2021-2022$ to $100 \mathrm{GW}$ by the year 2021-2022. In 2008-2009, it reached just 6 MW. The "Made in India" initiative to promote domestic manufacturing supported this great height in solar installation capacity. Currently, India has the fifth highest solar installed capacity worldwide. By the 31st of December 2018, solar energy had achieved 25,212.26 MW against the target of 2022, and a further $22.8 \mathrm{GW}$ of capacity has been tendered out or is under current implementation. MNRE is preparing to bid out the remaining solar energy capacity every year for the periods 2018-2019 and 20192020 so that bidding may contribute with $100 \mathrm{GW}$ capacity additions by March 2020. In this way, 2 years for the completion of projects would remain. Tariffs will be determined through the competitive bidding process (reverse e-auction) to bring down tariffs significantly. The lowest solar tariff was identified to be INR 2.44 per kWh in July 2018. In 2010, solar tariffs amounted to INR 18 per kWh. Over 100,000 lakh (10,000 million) acres of land had been classified for several planned solar parks, out of which over 75,000 acres had been obtained. As of November 2018, 47 solar parks of a total capacity of 26,694 MW were established. The aggregate capacity of $4195 \mathrm{MW}$ of solar projects has been commissioned inside various solar parks (floating solar power). Table 18 shows the capacity addition compared to the target. It indicates that capacity addition increased exponentially.

\section{Wind energy}

As of the 31st of December 2018, the total installed capacity of India amounted to $35,138.15 \mathrm{MW}$ compared to a target of $60 \mathrm{GW}$ by 2022. India is currently in fourth position in the world for installed capacity of wind power. Moreover, around 9.4 GW capacity has been tendered out or is under current implementation. The MNRE is preparing to bid out for A $10 \mathrm{GW}$ wind energy capacity every year for 2018-2019 and 2019-2020, so that bidding will allow for $60 \mathrm{GW}$ capacity additions by March 2020, giving the remaining two years for the accomplishment of the projects. The gross wind energy potential of the country now reaches $302 \mathrm{GW}$ at a $100 \mathrm{~m}$ above-ground level. The tariff administration has been changed from feed-in-tariff (FiT) to the bidding method for capacity addition. On the 8th of December 2017, the ministry published guidelines for a tariff-based competitive bidding rule for the acquisition of energy from gridconnected wind energy projects. The developed 
Table 11 The installed capacity of renewable energy in India_-source-wise (MW) [43]

\begin{tabular}{lllllcl}
\hline Financial year & Small hydro power (MW) & Wind (MW) & Biomass cogeneration (MW) & Waste-to-energy (MW) & $\begin{array}{c}\text { Solar (MW) } \\
\text { Total renewable } \\
\text { capacity (MW) }\end{array}$ \\
\hline As of 31.12.2018 & 4517.45 & $35,138.15$ & 9075.50 & 138.30 & 25212.26 & $74,081.66$ \\
$2017-2018$ & 4485.81 & $34,046.00$ & 8700.80 & 138.30 & 21651.48 & $69,022.39$ \\
$2016-2017$ & 4379.86 & $32,279.77$ & 8181.70 & 114.08 & 12288.83 & $57,244.23$ \\
$2015-2016$ & 4273.47 & $26,777.4$ & 4831.33 & 90.58 & 6762.85 & $45,924.04$ \\
$2014-2015$ & 4055.36 & $23,354.35$ & 4418.55 & 90.58 & 3743.97 & $38,959.16$ \\
$2013-2014$ & 3803.68 & $21,042.58$ & 4013.55 & 90.58 & 2631.93 & $34,988.00$ \\
$2012-2013$ & 3643.17 & $18,484.99$ & 3601.03 & 126.08 & 1686.44 & $27,541.71$ \\
$2011-2012$ & 3410.52 & $16,896.6$ & 3135.33 & 119.68 & 941.31 & $24,503.44$ \\
$2010-2011$ & 2913 & $12,806.54$ & 2600.13 & 102.46 & 32.39 & $18,454.52$ \\
$2009-2010$ & 2604.92 & $10,647.45$ & 2167.73 & 95.01 & 6 & $15,521.11$ \\
$2008-2009$ & 2160.48 & 9344.13 & 1650.43 & 85.25 & 85.75 & 2.12 \\
$2007-2008$ & 2045.07 & 7666.84 & 1325.63 & & $13,242.41$ \\
\hline
\end{tabular}

transparent process of bidding lowered the tariff for wind power to its lowest level ever. The development of the wind industry has risen in a robust ecosystem ensuring project execution abilities and a manufacturing base. State-of-the-art technologies are now available for the production of wind turbines. All the major global players in wind power have their presence in India. More than 12 different companies manufacture more than 24 various models of wind turbines in India. India exports wind turbines and components to the USA, Europe, Australia, Brazil, and other Asian countries. Around $70-80 \%$ of the domestic production has been accomplished with strong domestic manufacturing companies. Table 19 lists the capacity addition compared to the target for the capacity addition. Furthermore, electricity generation from the wind-based capacity has improved, even though there was a slowdown of new capacity in the first half of 2018-2019 and 2017-2018.

The national energy storage mission-2018

The country is working toward a National Energy Storage Mission. A draft of the National Energy Storage Mission was proposed in February 2018 and initiated to develop a comprehensive policy and regulatory framework. During the last 4 years, projects included in R\&D worth INR 115.8 million (USD 1.66 million) in the domain of energy storage have been launched, and a corpus of INR 48.2 million (USD 0.7 million) has been issued. India's energy storage mission will provide an opportunity for globally competitive battery manufacturing. By increasing the battery manufacturing expertise and scaling up its national production capacity, the country can make a substantial economic contribution in this crucial sector. The mission aims to identify the cumulative battery requirements, total market size, imports, and domestic manufacturing. Table 20 presents the economic opportunity from battery manufacturing given by the National Institution for Transforming India, also called NITI Aayog, which provides relevant technical advice to central and state governments while designing strategic and long-term policies and programs for the Indian government.

\section{Small hydropower-3-year action agenda-2017}

Hydro projects are classified as large hydro, small hydro ( 2 to $25 \mathrm{MW}$ ), micro-hydro (up to $100 \mathrm{~kW}$ ), and minihydropower (100 kW to $2 \mathrm{MW}$ ) projects. Whereas the estimated potential of SHP is $20 \mathrm{GW}$, the 2022 target for India in SHP is $5 \mathrm{GW}$. As of the 31st of December

Table 12 Cumulative installed renewable energy capacity shares [46, 47]

\begin{tabular}{|c|c|c|c|c|c|c|c|}
\hline Sources (GW) & 2002 & 2007 & 2012 & 2017 & 2022 & 2027 & 2032 \\
\hline Thermal & 74.4 & 86.0 & 131.6 & 218.3 & 296.1 & 389.3 & 552.4 \\
\hline Renewables & 3.4 & 10.2 & 24.9 & 57.3 & 175.0 & 250.4 & 350.4 \\
\hline Nuclear & 2.7 & 3.9 & 4.7 & 6.78 & 11.84 & 19.10 & 23.30 \\
\hline Large hydropower & 26.20 & 34.60 & 38.90 & 44.48 & 60.90 & 67.10 & 74.60 \\
\hline Total & 106.7 & 134.7 & 200.1 & 326.86 & 543.84 & 725.9 & 1000.7 \\
\hline Percentage of renewable energy shares in the total installed capacity & $3 \%$ & $8 \%$ & $12 \%$ & $18 \%$ & $32 \%$ & $34 \%$ & $35 \%$ \\
\hline
\end{tabular}




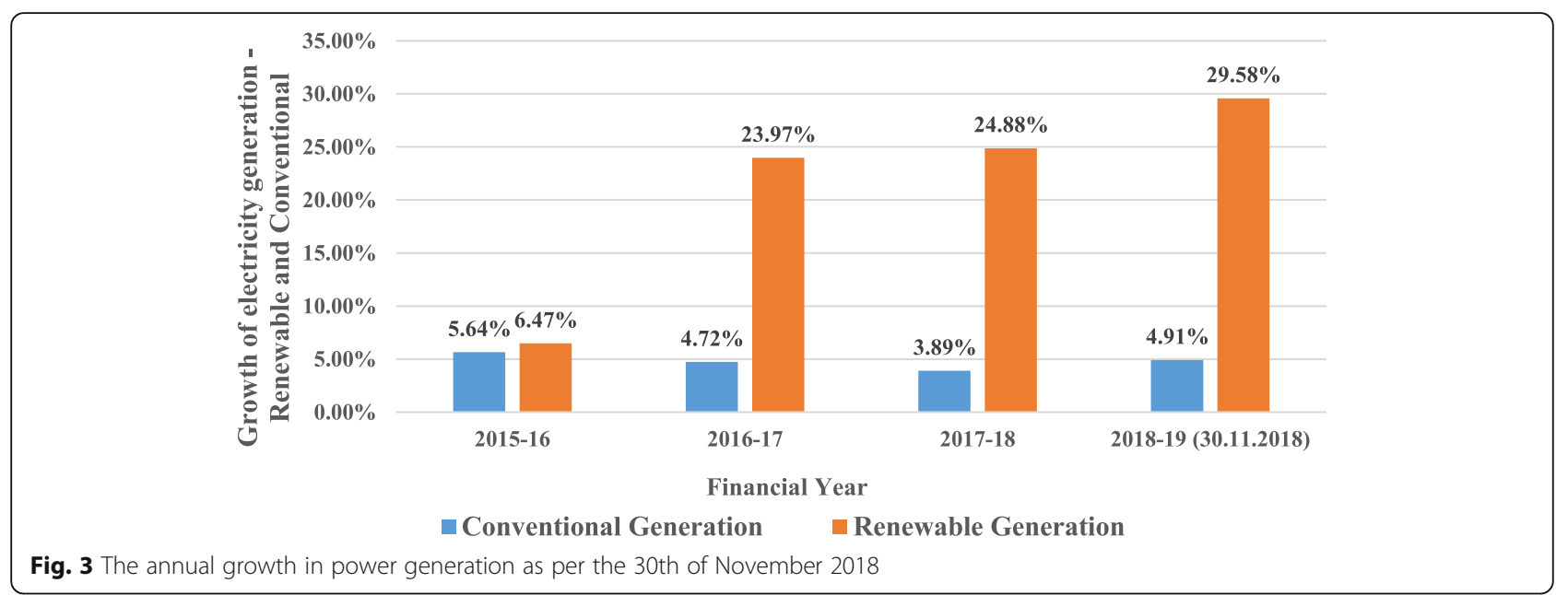

2018, the country has achieved 4.5 GW and this production is constantly increasing. The objective, which was planned to be accomplished through infrastructure project grants and tariff support, was included in the NITI Aayog's 3-year action agenda (2017-2018 to 2019-2020), which was published on the 1st of August 2017. MNRE is providing central financial assistance (CFA) to set up small/micro hydro projects both in the public and private sector. For the identification of new potential locations, surveys and comprehensive project reports are elaborated, and financial support for the renovation and modernization of old projects is provided. The Ministry has established a dedicated completely automatic supervisory control and data acquisition (SCADA)-based on a hydraulic turbine R\&D laboratory at the Alternate Hydro Energy Center (AHEC) at IIT Roorkee. The establishment cost for the lab was INR 40 crore (400 million INR, 95.62 Million USD), and the laboratory will serve as a design and validation facility. It investigates hydro turbines and other hydro-mechanical devices adhering to national and international standards [54,55]. Table 21 shows the target and achievements from 2007-2008 to 2018-2019.

\section{National policy regarding biofuels-2018}

Modernization has generated an opportunity for a stable change in the use of bioenergy in India. MNRE amended the current policy for biomass in May 2018. The policy presents CFA for projects using biomass such as agriculture-based industrial residues, wood produced through energy plantations, bagasse, crop residues, wood waste generated from industrial operations, and weeds. Under the policy, CFA will be provided to the projects at the rate of INR 2.5 million (USD 35,477.7) per MW for bagasse cogeneration and INR 5 million (USD 70,955.5) per MW for non-bagasse cogeneration. The MNRE also announced a memorandum in November 2018 considering the continuation of the concessional customs duty certificate (CCDC) to set up projects for the production of energy using non-conventional materials such as bio-waste, agricultural, forestry,

Table 13 Cumulative energy generation from renewable energy and conventional energy 2011-2019 [33]

\begin{tabular}{lll}
\hline & Energy generation from conventional sources (BU) & Energy generation from conventional sources (BU) \\
\hline $2010-2011$ & 811.143 & 9.860 \\
$2011-2012$ & 876.887 & 51.226 \\
$2012-2013$ & 912.056 & 57.449 \\
$2013-2014$ & 967.150 & 65.520 \\
$2014-2015$ & 1048.673 & 61.719 \\
$2015-2016$ & 1107.822 & 65.781 \\
$2016-2017$ & 1160.414 & 81.548 \\
$2017-2018$ & 1206.306 & 101.839 \\
$2018-2019(30.11 .2018)$ & 749.173 & 88.945 \\
\hline
\end{tabular}


Table 14 Cumulative electricity generation from renewable energy_region-wise [48]

\begin{tabular}{|c|c|c|c|c|}
\hline $\begin{array}{l}\text { Cumulative generation } \\
\text { achieved during } \\
\text { the year up to the } \\
\text { reporting month }(\mathrm{MU})\end{array}$ & $\begin{array}{l}\text { 2018-2019 } \\
\text { (April-November 2018) }\end{array}$ & $\begin{array}{l}\text { 2017-2018 } \\
\text { (April-March) }\end{array}$ & $\begin{array}{l}\text { 2016-2017 } \\
\text { (April-March) }\end{array}$ & $\begin{array}{l}\text { 2015-2016 } \\
\text { (April-March) }\end{array}$ \\
\hline Northern & $16,055.27$ & $21,388.22$ & $18,184.54$ & $15,917.51$ \\
\hline Western & $26,124.98$ & $31,564.48$ & $27,603.54$ & $22,958.91$ \\
\hline Southern & $44,768.78$ & $46,077.26$ & $33,137.87$ & $24,162.83$ \\
\hline Eastern & 1779.46 & 2516.78 & 2611.19 & 2425.30 \\
\hline North-Eastern & 216.85 & 292.75 & 331.55 & 316.30 \\
\hline Grand Total & $88,945.34$ & $101,839.48$ & $81,868.69$ & $65,780.85$ \\
\hline
\end{tabular}

poultry litter, agro-industrial, industrial, municipal, and urban wastes. The government recently established the National policy on biofuels in August 2018. The MNRE invited an expression of interest (EOI) to estimate the potential of biomass energy and bagasse cogeneration in the country. A program to encourage the promotion of biomass-based cogeneration in sugar mills and other industries was also launched in May 2018. Table 22 shows how the biomass power target and achievements are expected to reach $10 \mathrm{GW}$ of the target of 2022 before the end of 2019.

\section{The new national biogas and organic manure program (NNBOMP) - 2018}

The National biogas and manure management programme (NBMMP) was launched in 2012-2013. The primary objective was to provide clean gaseous fuel for cooking, where the remaining slurry was organic bio-manure which is rich in nitrogen, phosphorus, and potassium. Further, 47.5 lakh (4.75 million) cumulative biogas plants were completed in 2014, and increased to 49.8 lakh (4.98 million). During 2017-2018, the target was to establish 1.10 lakh biogas plants (1.10 million), but resulted in 0.15 lakh (0.015 million). In this way, the cost of refilling the gas cylinders with liquefied petroleum gas (LPG) was greatly reduced. Likewise, tons of wood/trees were protected from being axed, as wood is traditionally used as a fuel in rural and semi-urban households. Biogas is a viable alternative to traditional cooking fuels. The scheme generated employment for almost 300 skilled laborers for setting up the biogas plants. By 30th of May 2018, the Ministry had issued guidelines for the implementation of the NNBOMP during the period 2017-2018 to 2019-2020 [56].

\section{The off-grid and decentralized solar photovoltaic} application program-2018

The program deals with the energy demand through the deployment of solar lanterns, solar streetlights, solar

Table 15 Cumulative electricity generation from renewable energy_state-wise (states generating more than 1000 MU) [48]

\begin{tabular}{|c|c|c|c|c|}
\hline Renewable energy generation (MU) & 2018-19 (April-November 2018) & 2017-18 (April-March) & 2016-17 (April-March) & 2015-16 (April-March) \\
\hline Himachal Pradesh & 1989.26 & 1903.05 & 2110.71 & 1921.77 \\
\hline Punjab & 1544.73 & 2343.87 & 2149.49 & 1474.2 \\
\hline Rajasthan & 7912.68 & 9484.23 & 7973.85 & 6600.24 \\
\hline Uttar Pradesh & 2554.50 & 4606.29 & 3638.26 & 3201.49 \\
\hline Gujarat & 9670.07 & 11759.63 & 9497.99 & 8003.73 \\
\hline Madhya Pradesh & 5406.34 & 6292.9 & 5268.67 & 2910.42 \\
\hline Maharashtra & 9811.79 & 12036.98 & 11292.7 & 10756.58 \\
\hline Andhra Pradesh & 10602.81 & 10597.47 & 5488.26 & 3106.61 \\
\hline Telangana & 4503.35 & 4632.28 & 1999.89 & 1027.9 \\
\hline Karnataka & 14734.92 & 13463.98 & 9585.68 & 10061.03 \\
\hline Tamilnadu & 14073.94 & 16179.86 & 15153.87 & 9331.47 \\
\hline West Bengal & 1093.37 & 1590.54 & 1569.77 & 1608.15 \\
\hline Others & 5047.58 & 6948.4 & 6138.86 & 5777.26 \\
\hline Total Generation (MU) & 88945.34 & 101839.48 & 81868.69 & 65780.85 \\
\hline
\end{tabular}


Table 16 Cumulative energy generation from renewable energy—source-wise, 2014-2019 [48]

\begin{tabular}{llllllll}
\hline & Renewable generation (MU) & Wind & Solar energy & Biomass & Bagasse & Small Hydropower & WTE \\
\hline 2014-2015 & 61719 & 33,768 & 4599 & 3160 & 11,785 & 8060 & 348 \\
2015-2016 & 65781 & 33,029 & 7448 & 3727 & 12,953 & 8355 & 269 \\
$2016-2017$ & 81,548 & 46,004 & 13,499 & 4198 & 9960 & 7673 & 213 \\
2017-2018 & 101,839 & 52,666 & 25,871 & 3405 & 11,847 & 7692 & 358 \\
2018-2019 (up to 30.11.2018) & 88,945 & 50,335 & 24,506 & 1789 & 5140 & 6894 & 282 \\
\hline
\end{tabular}

home lights, and solar pumps. The plan intended to reach 118 MWp of off-grid PV capacity by 2020 . The sanctioning target proposed outlay was $50 \mathrm{MWp}$ by 2017-2018 and 68 MWp by 2019-2020. The total estimated cost amounted to INR 1895 crore (18950 Million INR, 265.547 million USD), and the ministry wanted to support 637 crores (6370 million INR, 89.263 million USD) by its central finance assistance. Solar power plants with a $25 \mathrm{KWp}$ size were promoted in those areas where grid power does not reach households or is not reliable. Public service institutions, schools, panchayats, hostels, as well as police stations will benefit from this scheme. Solar study lamps were also included as a component in the program. Thirty percent of financial assistance was provided to solar power plants. Every student should bear $15 \%$ of the lamp cost, and the ministry wanted to support the remaining $85 \%$. As of October 2018, lantern and lamps of more than 40 Lakhs (4 million), home lights of 16.72 lakhs (1.672 million) number, street lights of 6.40 lakhs (0.64 million), solar pumps of 1.96 lakhs (0.196 million), and 187.99 MWp stand-alone devices had been installed $[57,58]$.

\section{Major government initiatives for renewable energy}

\section{Technological initiatives}

The Technology Development and Innovation Policy (TDIP) released on the 6th of October 2017 was endeavored to promote research, development, and demonstration (RD\&D) in the renewable energy sector [59]. RD\&D intended to evaluate resources, progress in technology, commercialization, and the presentation of renewable energy technologies across the country. It aimed to produce renewable power devices and systems domestically. The evaluation of standards and resources, processes, materials, components, products, services, and subsystems was carried out through RD\&D. A development of the market, efficiency improvements, cost reductions, and a promotion of commercialization (scalability and bankability) were achieved through RD\&D. Likewise, the percentage of renewable energy in the total electricity mix made it self-sustainable, industrially competitive, and profitable through RD\&D. RD\&D also supported technology development and demonstration in wind, solar, wind-solar hybrid, biofuel, biogas, hydrogen fuel cells, and geothermal energies. RD\&D supported the R\&D units of educational institutions, industries, and non-government organizations (NGOs). Sharing expertise, information, as well as institutional mechanisms for collaboration was realized by use of the technology development program (TDP). The various people involved in this program were policymakers, industrial innovators, associated stakeholders and departments, researchers, and scientists. Renowned $R \& D$ centers in India are the National Institute of Solar Energy (NISE), Gurgaon, the National Institute of Bio-Energy (NIBE), Kapurthala, and the National Institute of Wind Energy (NIWE), Chennai. The TDP strategy encouraged the exploration of innovative approaches and possibilities to obtain long-term targets. Likewise, it efficiently supported the transformation of knowledge into technology through a well-established monitoring system for the development of renewable

Table 17 The past generation capacity and the estimation of the generation capacity (electricity mix) of renewable energy in India compared with conventional energy [51]

\begin{tabular}{lllll}
\hline TWh generation (BU) & $2011-2012$ & $2021-22$ & $2029-2030$ & $2046-2047$ \\
\hline Coal & 708.3 & 1444.7 & 1848 & 3153.6 \\
Gas & 115.4 & 127.7 & 155 & 198.1 \\
Nuclear & 26.7 & 82.5 & 109 & 183.1 \\
Hydro & 143.8 & 213.9 & 227 & 263 \\
Renewables & 58.6 & 213.1 & 424 & 1187.5 \\
Imports & 4.6 & 15.3 & 40 & 92 \\
Total & 1057 & 2097 & 2803 & 5077 \\
Share of renewable energy & $5.50 \%$ & $10.20 \%$ & $15 \%$ & $23.40 \%$ \\
\hline
\end{tabular}




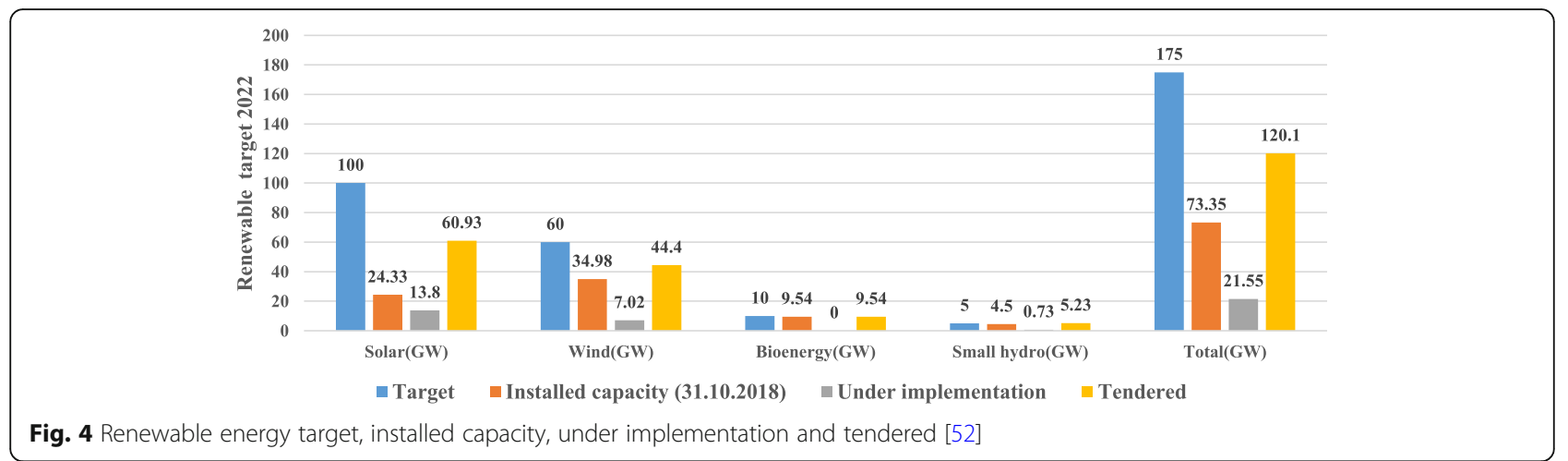

technology that meets the electricity needs of India. The research center of excellence approved the TDI projects, which were funded to strengthen R\&D. Funds were provided for conducting training and workshops. The MNRE is now preparing a database of R\&D accomplishments in the renewable energy sector.

The Impacting Research Innovation and Technology (IMPRINT) program seeks to develop engineering and technology (prototype/process development) on a national scale. IMPRINT is steered by the Indian Institute of Technologies (IITs) and Indian Institute of science (IISCs). The expansion covers all areas of engineering and technology including renewable technology. The ministry of human resource development (MHRD) finances up to $50 \%$ of the total cost of the project. The remaining costs of the project are financed by the ministry (MNRE) via the RD\&D program for renewable projects. Currently (2018-2019), five projects are under implementation in the area of solar thermal systems, storage for SPV, biofuel, and hydrogen and fuel cells which are funded by the MNRE (36.9 million INR, 0.518426 Million USD) and IMPRINT. Development of domestic technology and quality control are promoted through lab policies that were published on the 7th of December 2017. Lab policies were implemented to test, standardize, and certify renewable energy products and projects. They supported the improvement of the reliability and quality of the projects. Furthermore, Indian test labs are strengthened in line with international standards and practices through well-established lab policies. From 2015, the MNRE has provided "The New and Renewable Energy Young Scientist's Award" to researchers/scientists who demonstrate exceptional accomplishments in renewable R\&D.

\section{Financial initiatives}

One hundred percent financial assistance is granted by the MNRE to the government and NGOs and 50\% financial support to the industry. The policy framework was developed to guide the identification of the project, the formulation, monitoring appraisal, approval, and financing. Between 2012 and 2017, a 4467.8 million INR, 62.52 Million USD) support was granted by the MNRE. The MNRE wanted to double the budget for technology development efforts in renewable energy for the current three-year plan period. Table 23 shows that the government is spending more and more for the development of the renewable energy sector. Financial support was provided to R\&D projects. Exceptional consideration was given to projects that worked under extreme and hazardous conditions. Furthermore, financial support was applied to organizing awareness programs, demonstrations, training, workshops, surveys, assessment studies, etc. Innovative approaches will be rewarded with cash prizes. The winners will be presented with a support mechanism for transforming their ideas and prototypes

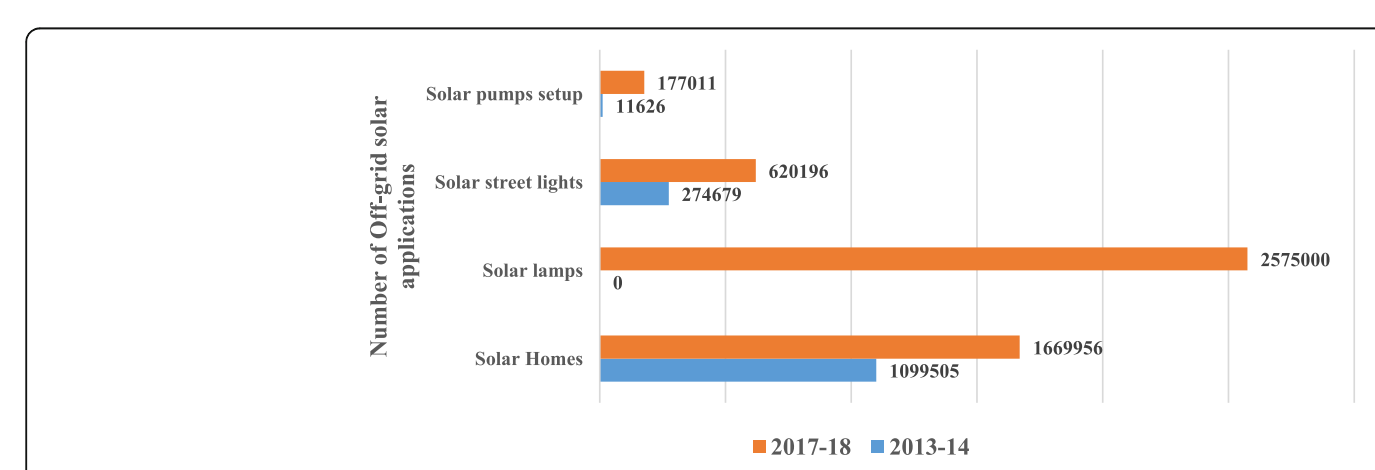

Fig. 5 Off-grid solar applications [52] 
Table 18 Solar capacity addition compared to the target between 2013-2014 and 2018-2019.

\begin{tabular}{|c|c|c|}
\hline \multirow[t]{2}{*}{ Year } & \multicolumn{2}{|c|}{$\begin{array}{l}\text { Solar power capacity additions in } \\
\text { MW }\end{array}$} \\
\hline & Target & Achievements \\
\hline 2013-2014 & 1100 & 962.1 \\
\hline 2014-2015 & 1100 & 1112 \\
\hline 2015-2016 & 1400 & 3019 \\
\hline 2016-2017 & 9100 & 5526 \\
\hline 2017-2018 & 10,000 & 9363 \\
\hline 2018-2019 (31st of December 2018) & 10,000 & 3270 \\
\hline
\end{tabular}

into marketable commodities such as start-ups for entrepreneur development. Innovative projects will be financed via start-up support mechanisms, which will include an investment contract with investors. The MNRE provides funds to proposals for investigating policies and performance analyses related to renewable energy.

Technology validation and demonstration projects and other innovative projects with regard to renewables received a financial assistance of $50 \%$ of the project cost. The CFA applied to partnerships with industry and private institutions including engineering colleges. Private academic institutions, accredited by a government accreditation body, were also eligible to receive a $50 \%$ support. The concerned industries and institutions should meet the remaining 50\% expenditure. The MNRE allocated an INR 3762.50 crore (INR 37625 million, 528.634 million USD) for the grid interactive renewable sources and an INR 1036.50 crore (INR 10365 million, 145.629 million USD) for off-grid/distributed and decentralized renewable power for the year 2018-2019 [60]. The MNRE asked the Reserve Bank of India (RBI), attempting to build renewable power projects under "priority sector lending" (priority lending should be done for renewable energy projects and without any limit) and to eliminate the obstacles in the financing of renewable energy projects. In July 2018, the Ministry of Finance announced that it would impose a $25 \%$ safeguard duty on

Table 19 Wind power capacity addition compared to the target between 2013-2014 and 2018-2019

\begin{tabular}{lll}
\hline Year & \multicolumn{2}{l}{ Wind power capacity addition in } \\
\cline { 2 - 3 } & MW & \\
\cline { 2 - 3 } $2013-2014$ & 2500 & 2083.3 \\
$2014-2015$ & 2000 & 2312 \\
$2015-2016$ & 2400 & 3423 \\
$2016-2017$ & 4000 & 5502 \\
$2017-2018$ & 4000 & 1766.25 \\
2018-2019 (31st of December 2018) & 4000 & 993.15 \\
\hline
\end{tabular}

solar panels and modules imported from China and Malaysia for 1 year. The quantum of tax might be reduced to $20 \%$ for the next 6 months, and $15 \%$ for the following 6 months.

\section{Policy and regulatory framework initiatives}

The regulatory interventions for the development of renewable energy sources are (a) tariff determination, (b) defining RPO, (c) promoting grid connectivity, and (d) promoting the expansion of the market.

\section{Tariff policy amendments-2018}

On the 30th of May 2018, the MoP released draft amendments to the tariff policy. The objective of these policies was to promote electricity generation from renewables. MoP in consultation with MNRE announced the long-term trajectory for RPO, which is represented in Table 24. The State Electricity Regulatory Commission (SERC) achieved a favorable and neutral/off-putting effect in the growth of the renewable power sector through their RPO regulations in consultation with the MNRE. On the 25th of May 2018, the MNRE created an RPO compliance cell to reach India's solar and wind power goals. Due to the absence of implementation of RPO regulations, several states in India did not meet their specified RPO objectives. The cell will operate along with the Central Electricity Regulatory Commission (CERC) and SERCs to obtain monthly statements on RPO compliance. It will also take up non-compliance associated concerns with the relevant officials.

\section{Repowering policy-2016}

On the 09th of August 2016, India announced a "repowering policy" for wind energy projects. An about $27 \mathrm{GW}$ turnaround was possible according to the policy. This policy supports the replacing of aging wind turbines with more modern and powerful units (fewer, larger, taller) to raise the level of electricity generation. This policy seeks to create a simplified framework and to promote an optimized use of wind power resources. It is mandatory because the up to the year 2000 installed wind turbines were below $500 \mathrm{~kW}$ in sites where high wind potential might be achieved. It will be possible to obtain $3000 \mathrm{MW}$ from the same location once replacements are in place. The policy was initially applied for the one MW installed capacity of wind turbines, and the MNRE will extend the repowering policy to other projects in the future based on experience. Repowering projects were implemented by the respective state nodal agencies/organizations that were involved in wind energy promotion in their states. The policy provided an exception from the Power Purchase Agreement (PPA) for wind farms/turbines undergoing repowering because they could not fulfill the requirements according to 
Table 20 Economic opportunity from battery manufacturing

\begin{tabular}{lllll}
\hline Stage & Cumulative battery requirements (GWh) & Total market size (INR lakh crore) & Imports & Domestic manufacturing \\
\hline I & 120 & $1.3-1.4$ & Cells & Battery packs \\
II & 970 & $6.1-8.9$ & Some cells, Cathode & Battery packs + limited cell production \\
III & 2410 & $11.7-17.1$ & Cathodes & End-to-end battery manufacturing \\
\hline
\end{tabular}

the PPA during repowering. The repowering projects may avail accelerated depreciation (AD) benefit or generationbased incentive (GBI) due to the conditions appropriate to new wind energy projects [61].

\section{The wind-solar hybrid policy-2018}

On the 14th of May 2018, the MNRE announced a national wind-solar hybrid policy. This policy supported new projects (large grid-connected wind-solar photovoltaic hybrid systems) and the hybridization of the already available projects. These projects tried to achieve an optimal and efficient use of transmission infrastructure and land. Better grid stability was achieved and the variability in renewable power generation was reduced. The best part of the policy intervention was that which supported the hybridization of existing plants. The tariff-based transparent bidding process was included in the policy. Regulatory authorities should formulate the necessary standards and regulations for hybrid systems. The policy also highlighted a battery storage in hybrid projects for output optimization and variability reduction [62].

\section{The national offshore wind energy policy-2015}

The National Offshore Wind Policy was released in October 2015. On the 19th of June 2018, the MNRE announced a medium-term target of 5 GW by 2022 and a long-term target of $30 \mathrm{GW}$ by 2030. The MNRE called expressions of Interest (EoI) for the first $1 \mathrm{GW}$ of offshore wind (the last date was 08.06.2018). The EoI site is located in Pipavav port at the Gulf of Khambhat at a distance of $23 \mathrm{~km}$ facilitating offshore wind (FOWIND) where the consortium deployed light detection and ranging (LiDAR) in November 2017). Pipavav port is situated off the coast of Gujarat. The MNRE had planned to install more such equipment in the states of Tamil Nadu and Gujarat. On the $14^{\text {th }}$ of December 2018, the MNRE, through the National Institute of Wind Energy (NIWE), called tender for offshore environmental impact assessment studies at intended LIDAR points at the Gulf of Mannar, off the coast of Tamil Nadu for offshore wind measurement. The timeline for initiatives was to firstly add 500 MW by 2022, 2 to 2.5 GW by 2027, and eventually reaching 5 GW between 2028 and 2032. Even though the installation of large wind power turbines in open seas is a challenging task, the government has endeavored to promote this offshore sector. Offshore wind energy would add its contribution to the already existing renewable energy mix for India [63].

\section{The feed-in tariff policy-2018}

On the 28th of January 2016, the revised tariff policy was notified following the Electricity Act. On the 30th May 2018, the amendment in tariff policy was released. The intentions of this tariff policy are (a) an inexpensive and competitive electricity rate for the consumers; (b) to attract investment and financial viability; (c) to ensure that the perceptions of regulatory risks decrease through predictability, consistency, and transparency of policy measures; (d) development in quality of supply, increased operational efficiency, and improved competition; (e)

Table 21 SHP target, achievements and cumulatives [54]

\begin{tabular}{llll}
\hline Year & Target(MW) & Achievement (MW) & Cumulative(MW) \\
\hline $2007-2008$ & 200 & 205 & 2045.07 \\
$2008-2009$ & 250 & 249 & 2160.48 \\
$2009-2010$ & 300 & 305 & 2604.92 \\
$2010-2011$ & 300 & 307 & 2913.00 \\
$2011-2012$ & 350 & 353 & 3410.52 \\
$2012-2013$ & 350 & 237 & 3643.17 \\
$2013-2014$ & 300 & 252 & 3803.68 \\
$2014-2015$ & 250 & 408 & 4055.36 \\
$2015-2016$ & 250 & 218 & 4273.47 \\
$2016-17$ & 250 & 105.9 & 4379.86 \\
$2017-18$ & 100 & 105.95 & 4485.80 \\
$2018-19$ (31st of December 2018) & 250 & 31.65 & 4517.45 \\
\hline
\end{tabular}


Table 22 Biomass power target, achievements and cumulatives

\begin{tabular}{llll}
\hline Year & $\begin{array}{l}\text { Target } \\
(\mathrm{MW})\end{array}$ & $\begin{array}{l}\text { Achievement } \\
(\mathrm{MW})\end{array}$ & $\begin{array}{l}\text { Cumulative } \\
(\mathrm{MW})\end{array}$ \\
\hline 2013-2014 & 405 & 412.5 & 4013.55 \\
2014-2015 & 400 & 405 & 4418.55 \\
2015-2016 & 400 & 400 & 4831.33 \\
2016-2017 & 400 & 161.95 & 8181.70 \\
2017-2018 & 340 & 519.10 & 8700.80 \\
2018-2019 (31.12.2018) & 250 & 374.70 & 9075.50 \\
\hline
\end{tabular}

increase the production of electricity from wind, solar, biomass, and small hydro; ( $\mathrm{f}$ ) peaking reserves that are acceptable in quantity or consistently good in quality or performance of grid operation where variable renewable energy source integration is provided through the promotion of hydroelectric power generation, including pumped storage projects (PSP); (g) to achieve better consumer services through efficient and reliable electricity infrastructure; (h) to supply sufficient and uninterrupted electricity to every level of consumers; and (i) to create adequate capacity, reserves in the production, transmission, and distribution that is sufficient for the reliability of supply of power to customers [64].

\section{Training and educational initiatives}

The MHRD has developed strong renewable energy education and training systems. The National Council for Vocational Training (NCVT) develops course modules, and a Modular Employable Skilling program (MES) in its regular 2-year syllabus to include SPV lighting systems, solar thermal systems, SHP, and provides the certificate for seven trades after the completion of a 2-year course. The seven trades are plumber, fitter, carpenter, welder, machinist, and electrician. The Ministry of Skill Development and Entrepreneurship (MSDE) worked out a national skill development policy in 2015. They provide regular training programs to create various job roles in renewable energy along with the MNRE support through a skill council for green jobs (SCGJ), the National Occupational Standards (NOS), and the Qualification Pack (QP). The SCGJ is promoted by the Confederation of Indian Industry (CII) and the MNRE. The industry partner for the SCGJ is ReNew Power $[65,66]$.

Table 23 Allocation budget for the MNRE (union budget 2018-2019) (R\&D)

\begin{tabular}{ll}
\hline Year & Allocation \\
\hline 2017-2018 (Budget estimate) & 5473 crore (5473 Million INR, \\
& 76.8991 Million USD) \\
2017-2018 (Revised estimate) & 4080 crore (4080 Million INR, \\
& 57.3266 Million USD) \\
2018-2019 (Budget estimate) & 5146.63 crore (51466.3 Million INR, \\
& 723.134 Million USD) \\
\hline
\end{tabular}

Table 24 Amended Tariff Policy, RPO trajectory up to 2019

\begin{tabular}{llll}
\hline Year & Solar energy & Non-Solar energy & Total \\
\hline $2016-2017$ & $2.75 \%$ & $8.75 \%$ & $11.50 \%$ \\
$2017-2018$ & $4.75 \%$ & $9.50 \%$ & $14.25 \%$ \\
$2018-2019$ & $6.75 \%$ & $10.25 \%$ & $17.00 \%$ \\
$2019-2020$ & $7.25 \%$ & $10.25 \%$ & $17.50 \%$ \\
$2020-2021$ & $8.75 \%$ & $10.25 \%$ & $19.00 \%$ \\
$2021-2022$ & $10.50 \%$ & $10.50 \%$ & $21.00 \%$ \\
\hline
\end{tabular}

\section{The global status of India in renewable energy}

Table 25 shows the RECAI (Renewable Energy Country Attractiveness Index) report of 40 countries. This report is based on the attractiveness of renewable energy investment and deployment opportunities. RECAI is based on macro vitals such as economic stability, investment climate, energy imperatives such as security and supply, clean energy gap, and affordability. It also includes policy enablement such as political stability and support for renewables. Its emphasis lies on project delivery parameters such as energy market access, infrastructure, and distributed generation, finance, cost and availability, and transaction liquidity. Technology potentials such as natural resources, power take-off attractiveness, potential support, technology maturity, and forecast growth are taken into consideration for ranking. India has moved to the fourth position of the RECAI-2018. Indian solar installations (new large-scale and rooftop solar capacities) in the calendar year 2017 increased exponentially with the addition of $9629 \mathrm{MW}$, whereas in 2016 it was $4313 \mathrm{MW}$. The warning of solar import tariffs and conflicts between developers and distribution firms are growing investor concerns [67]. Figure 6 shows the details of the installed capacity of global renewable energy in 2016 and 2017. Globally, 2017 GW renewable energy was installed in 2016, and in 2017, it increased to 2195 GW. Table 26 shows the total capacity addition of top countries until 2017. The country ranked fifth in renewable power capacity (including hydro energy), renewable power capacity (not including hydro energy) in fourth position, concentrating solar thermal power (CSP) and wind power were also in fourth position [68].

\section{The investment opportunities in renewable energy in India}

The investments into renewable energy in India increased by $22 \%$ in the first half of 2018 compared to 2017, while the investments in China dropped by $15 \%$ during the same period, according to a statement by the Bloomberg New Energy Finance (BNEF), which is shown in Table $27[69,70]$. At this rate, India is expected to overtake China and become the 
Table 25 Country attractive index of the $52^{\text {nd }}$ edition-201 of Renewable energy 8 [67]

\begin{tabular}{|c|c|c|c|c|c|c|c|c|c|c|c|}
\hline \multirow{2}{*}{$\begin{array}{l}\text { Overall } \\
\text { rank }\end{array}$} & \multirow{2}{*}{$\begin{array}{l}\text { Previous } \\
\text { rank }\end{array}$} & \multirow[t]{2}{*}{ Country } & \multirow{2}{*}{$\begin{array}{l}\text { RECAl } \\
\text { score }\end{array}$} & \multicolumn{8}{|c|}{ Technology-specific score (out of 100) } \\
\hline & & & & Onshore wind & Offshore wind & Solar PV & Solar CSP & Biomass & Geothermal & Hydro power & Marine \\
\hline 1 & 1 & China & 65.7 & 51 & 55 & 53 & 33 & 45 & 21 & 52 & 19 \\
\hline 2 & 2 & USA & 63.8 & 50 & 53 & 49 & 32 & 39 & 39 & 35 & 31 \\
\hline 3 & 4 & India & 63.8 & 50 & 20 & 57 & 34 & 44 & 25 & 45 & 21 \\
\hline 4 & 3 & Germany & 62.7 & 46 & 50 & 49 & 17 & 44 & 34 & 35 & 20 \\
\hline 5 & 6 & France & 62.5 & 50 & 51 & 48 & 22 & 48 & 33 & 31 & 36 \\
\hline 6 & 5 & Australia & 62.3 & 47 & 30 & 54 & 35 & 24 & 21 & 39 & 31 \\
\hline 7 & 8 & Japan & 59.2 & 43 & 44 & 47 & 18 & 51 & 48 & 36 & 23 \\
\hline 8 & 7 & UK & 58.6 & 47 & 57 & 41 & 14 & 47 & 27 & 32 & 33 \\
\hline 9 & 9 & Netherlands & 58.6 & 44 & 48 & 45 & 15 & 33 & 23 & 24 & 15 \\
\hline 10 & 13 & Argentina & 58.6 & 45 & 21 & 50 & 30 & 37 & 32 & 37 & 20 \\
\hline 11 & 11 & Chile & 56.7 & 43 & 20 & 47 & 32 & 37 & 31 & 41 & 28 \\
\hline 12 & 15 & Morocco & 56.6 & 42 & 17 & 51 & 31 & 16 & 15 & 20 & 14 \\
\hline 13 & 12 & Mexico & 56.3 & 43 & 19 & 50 & 25 & 45 & 43 & 34 & 19 \\
\hline 14 & 10 & Denmark & 55.7 & 44 & 48 & 39 & 15 & 44 & 17 & 22 & 24 \\
\hline 15 & 20 & Egypt & 54.9 & 45 & 14 & 52 & 36 & 13 & 12 & 27 & 12 \\
\hline
\end{tabular}

most significant growth market for renewable energy by the end of 2020. The country is eyeing pole position for transformation in renewable energy by reaching 175 GW by 2020. To achieve this target, it is quickly ramping up investments in this sector. The country added more renewable capacity than conventional capacity in 2018 when compared to 2017. India hosted the ISA first official summit on the 11.03.2018 for 121 countries. This will provide a standard platform to work toward the ambitious targets for renewable energy. The summit will emphasize India's dedication to meet global engagements in a time-bound method. The country is also constructing many sizeable solar power parks comparable to, but larger than, those in
China. Half of the earth's ten biggest solar parks under development are in India.

In 2014, the world largest solar park was the Topaz solar farm in California with a $550 \mathrm{MW}$ facility. In 2015, another operator in California, Solar Star, edged its capacity up to 579 MW. By 2016, India's Kamuthi Solar Power Project in Tamil Nadu was on top with $648 \mathrm{MW}$ of capacity (set up by the Adani Green Energy, part of the Adani Group, in Tamil Nadu). As of February 2017, the Longyangxia Dam Solar Park in China was the new leader, with 850 MW of capacity [71]. Currently, there are $600 \mathrm{MW}$ operating units and $1400 \mathrm{MW}$ units under construction. The Shakti

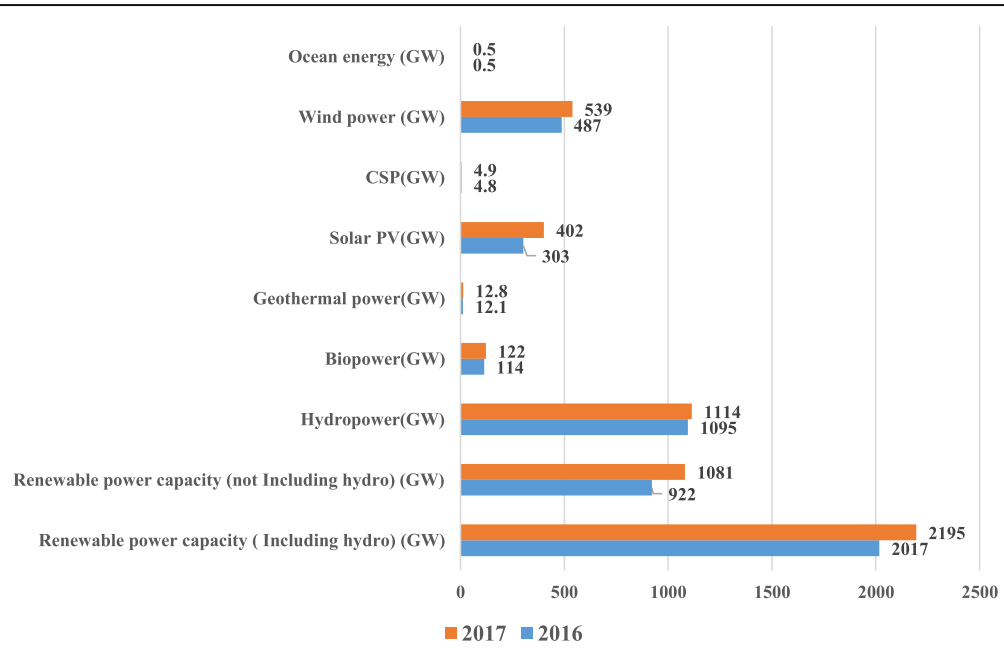

Fig. 6 Globally installed capacity of renewable energy in 2017-Global 2018 status report with regard to renewables [68] 
Table 26 Globally installed capacity of renewable energy in 2017—Global 2018 status report with regard to the ranking of renewables [68]

\begin{tabular}{|c|c|c|c|c|c|}
\hline Installed capacity & Rank I & Rank II & Rank III & Rank IV & Rank V \\
\hline Renewable power capacity (Including hydropower) & China & USA & Brazil & Germany & India \\
\hline Renewable power capacity (not Including hydropower) & China & USA & Germany & India & Japan \\
\hline Bio power & China & USA & Brazil & Germany & Japan \\
\hline Geothermal power & USA & Philippines & Indonesia & Turkey & New Zealand \\
\hline Hydropower & China & Brazil & Canada & USA & Russia \\
\hline Solar PV & China & USA & Japan & Germany & Italy \\
\hline CSP & Spain & USA & South Africa & India & Morocco \\
\hline Wind power & China & USA & Germany & India & Spain \\
\hline
\end{tabular}

Sthala solar park was inaugurated on 01.03.2018 in Pavagada (Karnataka, India) which is expected to become the globe's most significant solar park when it accomplishes its full potential of $2 \mathrm{GW}$. Another large solar park with $1.5 \mathrm{GW}$ is scheduled to be built in the Kadappa region [72]. The progress in solar power is remarkable and demonstrates real clean energy development on the ground.

The Kurnool ultra-mega solar park generated 800 million units (MU) of energy in October 2018 and saved over 700,000 tons of $\mathrm{CO}_{2}$. Rainwater was harvested using a reservoir that helps in cleaning solar panels and supplying water. The country is making remarkable progress in solar energy. The Kamuthi solar farm is cleaned each day by a robotic system. As the Indian economy expands, electricity consumption is forecasted to reach 15 , 280 TWh in 2040. With the government's intent, green energy objectives, i.e., the renewable sector, grow considerably in an attractive manner with both foreign and domestic investors. It is anticipated to attract investments of up to USD 80 billion in the subsequent 4 years. The government of India has raised its $175 \mathrm{GW}$ target to 225 GW of renewable energy capacity by 2022 . The competitive benefit is that the country has sun exposure possible throughout the year and has an enormous hydropower potential. India was also listed fourth in the EY renewable energy country attractive index 2018. Sixty solar cities will be built in India as a section of MNRE's "Solar cities" program.

In a regular auction, reduction in tariffs cost of the projects are the competitive benefits in the country. India accounts for about $4 \%$ of the total global electricity generation capacity and has the fourth highest installed capacity of wind energy and the third highest installed capacity of CSP. The solar installation in India erected during 2015-2016, 2016-2017, 2017-2018, and 20182019 was 3.01 GW, $5.52 \mathrm{GW}, 9.36 \mathrm{GW}$, and 6.53 GW, respectively. The country aims to add $8.5 \mathrm{GW}$ during 2019-2020. Due to its advantageous location in the solar belt (400 South to 400 North), the country is one of the

Table 27 New investments in renewable energy-renewable energy investment trends 2Q 2018 [69]

\begin{tabular}{llllllllllllll}
\hline \$bn & 2005 & 2006 & 2007 & 2008 & 2009 & 2010 & 2011 & 2012 & 2013 & 2014 & 2015 & 2016 & 2017 \\
\hline USA & 16.5 & 34.6 & 47.1 & 43.6 & 35.1 & 46.6 & 62.3 & 52.9 & 44.6 & 52.2 & 58.4 & 56.4 & 56.9 \\
Europe & 38.9 & 53.1 & 75.2 & 88.3 & 91.3 & 123.1 & 137.8 & 96.4 & 70.2 & 78.5 & 73.8 & 77.7 & 57.4 \\
China & 8.8 & 11.2 & 16.8 & 26.6 & 38.7 & 45.0 & 51.5 & 62.6 & 66.9 & 89.6 & 125.4 & 107.2 & 132.6 \\
Brazil & 2.7 & 5.1 & 9.8 & 11.5 & 7.9 & 7.5 & 10.3 & 8.2 & 4.4 & 7.8 & 6.7 & 5.7 & 6.2 \\
Canada & 2.1 & 2.5 & 4.2 & 3.3 & 3.6 & 6.6 & 4.0 & 5.8 & 6.7 & 7.0 & 3.8 & 2.3 & 3.3 \\
Mexico & 0.2 & 0.1 & 0.1 & 0.7 & 0.4 & 2.5 & 0.4 & 1.6 & 1.9 & 2.3 & 1.8 & 1.0 & 6.2 \\
UK & 4.7 & 6.2 & 6.8 & 5.9 & 11.9 & 10.8 & 13.1 & 11.7 & 15.1 & 17.5 & 25.9 & 23.4 & 10.3 \\
Germany & 15.2 & 17.0 & 20.2 & 21.7 & 27.6 & 40.3 & 39.0 & 27.4 & 18.8 & 24.0 & 18.5 & 19.8 & 14.6 \\
France & 3.2 & 5.3 & 4.9 & 5.6 & 4.6 & 6.3 & 10.5 & 7.0 & 5.2 & 7.3 & 4.1 & 4.3 & 5.0 \\
Spain & 5.2 & 9.9 & 23.3 & 23.2 & 9.9 & 8.1 & 10.6 & 3.0 & 1.2 & 0.8 & 0.1 & 0.8 & 1.1 \\
Italy & 2.4 & 2.0 & 3.8 & 8.1 & 8.4 & 24.3 & 32.3 & 15.6 & 4.3 & 1.7 & 2.1 & 2.2 & 2.5 \\
Japan & 8.4 & 8.1 & 9.4 & 11.3 & 12.5 & 14.8 & 18.6 & 25.0 & 37.3 & 44.3 & 42.6 & 27.9 & 23.4 \\
India & 3.2 & 5.4 & 6.4 & 5.8 & 4.3 & 9.0 & 13.8 & 8.1 & 6.8 & 8.5 & 9.9 & 13.7 & 11.0 \\
Australia & 1.4 & 1.8 & 1.5 & 1.5 & 2.3 & 5.2 & 6.2 & 5.4 & 4.8 & 2.2 & 2.2 & 3.6 & 9.0 \\
\hline
\end{tabular}


largest beneficiaries of solar energy with relatively ample availability. An increase in the installed capacity of solar power is anticipated to exceed the installed capacity of wind energy, approaching $100 \mathrm{GW}$ by 2022 from its current levels of 25.21226 GW as of December 2018. Fast falling prices have made Solar PV the biggest market for new investments. Under the Union Budget 2018-2019, a zero import tax on parts used in manufacturing solar panels was launched to provide an advantage to domestic solar panel companies [73].

Foreign direct investment (FDI) inflows in the renewable energy sector of India between April 2000 and June 2018 amounted to USD 6.84 billion according to the report of the department of industrial policy and promotion (DIPP). The DIPP was renamed (gazette notification 27.01.2019) the Department for the Promotion of Industry and Internal Trade (DPIIT). It is responsible for the development of domestic trade, retail trade, trader's welfare including their employees as well as concerns associated with activities in facilitating and supporting business and startups. Since 2014, more than 42 billion USD have been invested in India's renewable power sector. India reached US\$ 7.4 billion in investments in the first half of 2018. Between April 2015 and June 2018, the country received USD 3.2 billion FDI in the renewable sector. The yearwise inflows expanded from USD 776 million in 20152016 to USD 783 million in 2016-2017 and USD 1204 million in 2017-2018. Between January to March of 2018, the INR 452 crore (4520 Million INR, 63.3389 million USD) of the FDI had already come in. The country is contributing with financial and promotional incentives that include a capital subsidy, accelerated depreciation (AD), waiver of inter-state transmission charges and losses, viability gap funding (VGF), and FDI up to $100 \%$ under the automated track.

The DIPP/DPIIT compiles and manages the data of the FDI equity inflow received in India [74]. The FDI equity inflow between April 2015 and June 2018 in the renewable sector is illustrated in Fig. 7. It shows that the 2018-2019 3 months' FDI equity inflow is half of that of the entire one of 2017-2018. It is evident from the figure that India has well-established FDI equity inflows. The significant FDI investments in the renewable energy sectors are shown in Table 28. The collaboration between the Asian development bank and Renew Power Ventures private limited with 44.69 million USD ranked first followed by AIRRO Singapore with Diligent power with FDI equity inflow of 44.69 USD million.

\section{Strategies to promote investments}

Strategies to promote investments (including FDI) by investors in the renewable sector:

- Decrease constraints on FDI; provide open, transparent, and dependable conditions for foreign and domestic firms; and include ease of doing business, access to imports, comparatively flexible labor markets, and safeguard of intellectual property rights.

- Establish an investment promotion agency (IPA) that targets suitable foreign investors and connects them as a catalyst with the domestic economy. Assist the IPA to present top-notch infrastructure and immediate access to skilled workers, technicians, engineers, and managers that might be needed to attract such investors. Furthermore, it should involve an after-investment care, recognizing the demonstration effects from satisfied investors, the potential for reinvestments, and the potential for clusterdevelopment due to follow-up investments.

- It is essential to consider the targeted sector (wind, solar, $\mathrm{SPH}$ or biomass, respectively) for which investments are required.

- Establish the infrastructure needed for a quality investor, including adequate close-by transport facilities (airport, ports), a sufficient and steady supply of energy, a provision of a sufficiently

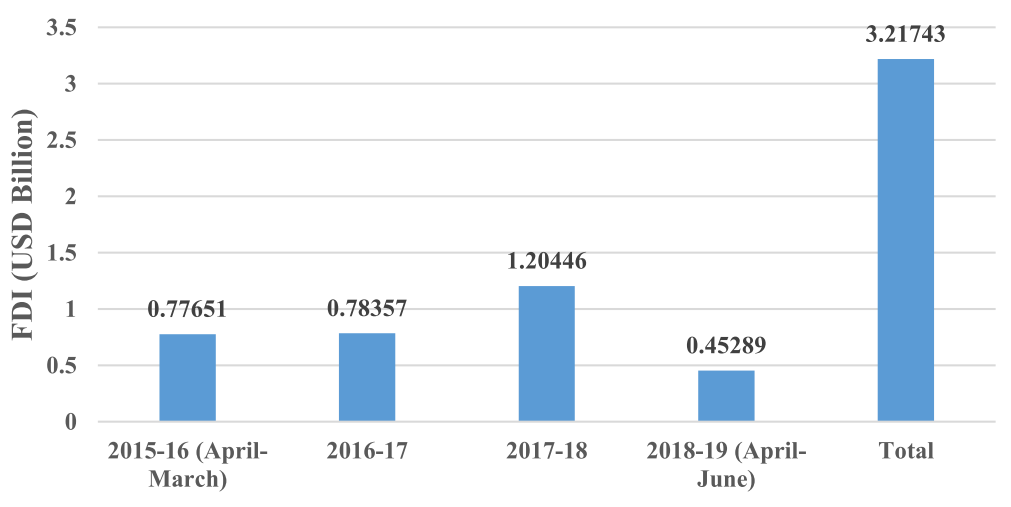

Financial year

Fig. 7 The FDI equity inflow received between April 2015 and June 2018 in the renewable energy sector [73] 
skilled workforce, the facilities for the vocational training of specialized operators, ideally designed in collaboration with the investor.

- Policy and other support mechanisms such as Power Purchase Agreements (PPA) play an influential role in underpinning returns and restricting uncertainties for project developers, indirectly supporting the availability of investment. Investors in renewable energy projects have historically relied on government policies to give them confidence about the costs necessary for electricity produced-and therefore for project revenues. Reassurance of future power costs for project developers is secured by signing a PPA with either a utility or an essential corporate buyer of electricity.

- FiT have been the most conventional approach around the globe over the last decade to stimulate investments in renewable power projects. Set by the government concerned, they lay down an electricity tariff that developers of qualifying new projects might anticipate to receive for the resulting electricity over a long interval (15-20 years). These present investors in the tax equity of renewable power projects with a credit that they can manage to offset the tax burden outside in their businesses.

- Table 29 presents the 2018 renewable energy investment report, source-wise, by the significant players in renewables according to the report of the Bloomberg New Energy Finance Report 2018. As per this report, global investment in renewable energy was USD of 279.8 billion in 2017. The top ten in the total global investments are China (126.1 \$BN), the USA $(40.5 \$ \mathrm{BN})$, Japan (13.4 \$BN), India (10.9 \$BN), Germany (10.4 $\$ \mathrm{BN})$, Australia $(8.5$ \$BN), UK (7.6 \$BN), Brazil (6.0 $\$ \mathrm{BN})$, Mexico (6.0 \$BN), and Sweden (3.7 \$BN) [75]. This achievement was possible since those countries have well-established strategies for promoting investments $[76,77]$.

The appropriate objectives for renewable power expansion and investments are closely related to the
Nationally Determined Contributions (NDCs) objectives, the implementation of the NDC, on the road to achieving Paris promises, policy competence, policy reliability, market absorption capacity, and nationwide investment circumstances that are the real purposes for renewable power expansion, which is a significant factor for the investment strategies, as is shown in Table 30.

The demand for investments for building a Pariscompatible and climate-resilient energy support remains high, particularly in emerging nations. Future investments in energy grids and energy flexibility are of particular significance. The strategies and the comparison chart between China, India, and the USA are presented in Table 31.

Table 32 shows France in the first place due to overall favorable conditions for renewables, heading the G20 in investment attractiveness of renewables. Germany drops back one spot due to a decline in the quality of the global policy environment for renewables and some insufficiencies in the policy design, as does the UK. Overall, with four European countries on top of the list, Europe, however, directs the way in providing attractive conditions for investing in renewables. Despite high scores for various nations, no single government is yet close to growing a role model. All countries still have significant room for increasing investment demands to deploy renewables at the scale required to reach the Paris objectives. The table shown is based on the Paris compatible long-term vision, the policy environment for renewable energy, the conditions for system integration, the market absorption capacity, and general investment conditions. India moved from the 11th position to the 9th position in overall investments between 2017 and 2018 .

A Paris compatible long-term vision includes a decarbonization plan for the power system, the renewable power ambition, the coal and oil decrease, and the reliability of renewables policies. Direct support policies include medium-term certainty of policy signals, streamlined administrative procedures, ensuring project realization, facilitating the use of produced electricity.

Table 28 Leading FDI investments in the renewable energy sector [74]

\begin{tabular}{llll}
\hline Collaborating company & Country & Indian company/Private limited & FDI equity inflow (USD mn) \\
\hline Asian Development Bank & Philippines & Renew Power Ventures & 44.69 \\
AIRRO Singapore Pte Ltd & Singapore & Diligent Power & 41.07 \\
ORIX Corporation & Japan & TADAS Wind Energy & 37.75 \\
ENEL Green Power Development B.V. & Netherlands & BLP Energy & 32.61 \\
DEG - Deutsche Investitions- und Entwicklungsgesellschaft & Germany & WELSPUN Renewables Energy & 32.50 \\
ENERK International Holdings Ltd & Seychelles & RKM POWERGEN & 32.50 \\
OSTRO Renewal Power Limited & Mauritius & OSTRO Energy & 32.21 \\
AREVA Solar Inc. & USA & AREVA Solar India & 31.53 \\
\hline
\end{tabular}


Table 29 Renewable energy investment report_-developing economies-source-wise (Bloomberg New Energy Finance report 2018) [75]

\begin{tabular}{llllll}
\hline USD billion & China & India & Brazil & USA & Europe \\
\hline Solar & 86.5 & 6.7 & 2.1 & 19.8 & 10.8 \\
Wind & 36.1 & 4.0 & 3.6 & 19.2 & 28.0 \\
Biofuels & 0.1 & 0.0 & 0.2 & 0.7 & 0.6 \\
Biomass & 1.5 & 0.1 & 0.0 & 0.4 & 1.0 \\
Small hydropower & 2.4 & 0.1 & 0.1 & 0.1 & 0.2 \\
Total (\$BN) & 126.6 & 10.9 & 6.0 & 40.2 & 40.6 \\
\hline
\end{tabular}

Conditions for system integration include system integration-grid codes, system integration-storage promotion, and demand-side management policies. A market absorption capacity includes a prior experience with renewable technologies, a current activity with renewable installations, and a presence of major renewable energy companies. General investment conditions include non-financial determinants, depth of the financial sector as well, as an inflation forecast.

\section{Employment opportunities for citizens in renewable energy in India Global employment scenario}

According to the 2018 Annual review of the IRENA [78], global renewable energy employment touched 10.3 million jobs in 2017, an improvement of 5.3\% compared with the quantity published in 2016. Many socioeconomic advantages derive from renewable power, but employment continues to be exceptionally centralized in a handful of countries, with China, Brazil, the USA, India, Germany, and Japan in the lead. In solar PV employment (3.4 million jobs), China is the leader (65\% of PV Jobs) which is followed by Japan, USA, India, Bangladesh, Malaysia, Germany, Philippines, and Turkey.

Table $\mathbf{3 0}$ Targets relevant for renewable energy development [76]

\begin{tabular}{|c|c|c|c|}
\hline $\begin{array}{l}\text { Objectives appropriate } \\
\text { for renewable power } \\
\text { expansion and } \\
\text { facilitating } \\
\text { investments }\end{array}$ & China & India & USA \\
\hline NDC purpose & $\begin{array}{l}\text { By } 2030 \text {, an approx. } 20 \% \text { rise of non- } \\
\text { fossil fuels in the primary energy mix, by } \\
2030 \text { carbon intensity of GDP lowered } \\
\text { by } 60 \% \text { to } 65 \% \text { under the } 2005 \text { levels, } \\
\text { by } 2020 \text {, an approx. } 10 \% \text { rise of natural } \\
\text { gas in the primary energy mix, latest by }\end{array}$ & $\begin{array}{l}\text { By } 2030 \text {, an approx. } 40 \% \text { rise of non- } \\
\text { fossil fuels in the primary energy mix, by } \\
\text { 2030, the carbon intensity of GDP low- } \\
\text { ered by } 33 \% \text { to } 35 \% \text { under the } 2005 \\
\text { levels. }\end{array}$ & $\begin{array}{l}\text { Reduce the emissions intensity of GDP } \\
\text { by } 26-28 \% \text { by } 2025 \text { below } 2005 \text { levels } \\
\text { (incl. LULUCF) and reduce the emissions } \\
\text { intensity of GDP by } 83 \% \text { by } 2050 \text { below } \\
2005 \text { levels (excl. LULUCF- land use } \\
\text { change and forestry) }\end{array}$ \\
\hline
\end{tabular}

NDC implementation In 2015, the installed renewable capacity (including hydro energy) in China amounted to $493 \mathrm{GW}$ and it is planned in the thirteenth renewable energy development five year plan to achieve 680 GW by 2020

On the route of reaching Paris promises
China is anticipated to accomplish its objectives with its contemporary policies.
It is recommended in the National Action Plan on Climate Change (NAPCC) to achieve a $15 \%$ share of renewables power in the total power generation, and the National solar mission is targeting $175 \mathrm{GW}$ by 2020. In the draft of the National Electricity Plan (2016), it is predicted that the share of the installed capacity (renewables, nuclear and hydro energy) of non-fossil fuels will reach $56.5 \%$ by $2026-2027$. Furthermore, there will be a $20.3 \%, 24.2 \%$ share of renewables in energy production in 20212022 and 2026-2027, respectively.

India is anticipated to accomplish its objectives with its contemporary policies.

High

High

very low

Very low
The individual states power-sector associated emissions reduction cumulatively to $32 \%$ below 2005 levels by 2030 is described in the Clean Power Plan (CPP).

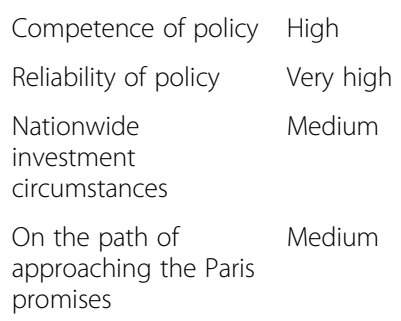

A closed-down Obama's Clean Power Plan (CPP) could prevent the US growth for accomplishing its Paris Agreement objectives. Executive order to halt the CPP in March 2017 was signed by the new administration.

Low

Low

Medium 
Table 31 Strategies of the development of renewable energy investments [76]

\begin{tabular}{|c|c|}
\hline Strategies for investments & China \\
\hline $\begin{array}{l}\text { Adequacy and reliability of } \\
\text { renewable power policies } \\
\text { (Strong policies) are essential } \\
\text { for investors to realize the } \\
\text { required range of investments. }\end{array}$ & $\begin{array}{l}\text { The findings in the } 2016 \text { Allianz } \\
\text { Climate \& Energy Monitor's report } \\
\text { conclude that China and India are } \\
\text { competing more effectively as the } \\
\text { USA in implementing a robust, } \\
\text { nation-wide green policy } \\
\text { environment. This trend is } \\
\text { anticipated to continue stable } \\
\text { in } 2017 \text {. Strong policies help to } \\
\text { achieve the Paris climate } \\
\text { objectives of India and China } \\
\text { whereas the USA might miss its } \\
\text { goals to fulfill the targets of the } \\
\text { Paris Agreement if the current } \\
\text { government swiftly performs its } \\
\text { current announcements. Without } \\
\text { attractive and strong nation-wide } \\
\text { policies in the USA, renewable } \\
\text { powers encounter headwinds } \\
\text { (opposite general direction to a } \\
\text { course of movement) and will rely } \\
\text { on their state actions and imminent } \\
\text { cost competitiveness. }\end{array}$ \\
\hline
\end{tabular}

Additions to renewable energy capacity

Coal power plants decommissioning

A mature market

Paris agreement intentions

The investment volumes
The level of renewable energy capacity additions goes up currently in all three countries and has in total moved up to an overtook of investments in fossil-fuel based capacity additions. China is decreasing the use of coal at a sharp angle, firstly, to fight against environmental pollution and secondly due to the steady increase of renewables and a structural transformation steering in the economy of China.

China is quickly decommissioning coal power plants to fight against environmental pollution, and carbon emissions, whereas India may not put a hold onto developing new capacities before 2022.

Large quantities of renewable power investments in the USA are still in progressive because there are a mature market, an excellent general investment climate, and attractive state-level policies.

Renewable power leadership of the USA, India, and China is significant to meet the Paris agreement intentions.

India continued the stable growth in the investment volumes compared to China and the USA. The investment volume fell in the two countries. In China, the drop was 32\% (USD 78 billion) because the country was giving priority to integrating the already-existing renewable capacity. In the USA, the decline amounted to 10\% (USD 46 billion) because the country was giving priority to pushing installations in 2015 to avoid the potential federal tax credits' expiration in 2016. The total global newly

Table 31 Strategies of the development of renewable energy investments [76] (Continued)

\begin{tabular}{ll}
\hline Strategies for investments & China India \\
\hline & installed capacity still increased from \\
& 2015 to 2016, even though the \\
& investment costs per unit declined \\
& considerably. \\
Projection of absolute & Absolute investment predictions until \\
investment & of the investment demands estimation. \\
& The individual energy set-up of all \\
& country and current consumption \\
& patterns are significant determinants \\
& of future demands. For example, the \\
& USA has much more substantial power \\
& consumption than China and India \\
& today, while the consumption is rising \\
in China and India which implicates \\
expanding development needs.
\end{tabular}

Essential socio-economic indicators.

According to pre-estimation results of 2016, India has the most significant demand for renewable investments among the G20 members as an effect of comparatively low per-capita consumption, a fast-growing population and rising energy demands due to economic development. Despite a mature market and high energy consumption, in terms of investment required, the USA is close to India and China, reflecting a powerful vulnerability of its energy infrastructure to climate effects.

Developing a policy framework of renewable energy for long-term investment

\begin{abstract}
China and India are continually developing its policy framework for long-term renewable energy investments and, at a federal level; the outlook for the USA is worsening. The modern renewable policy environment in China and India is more efficient and stable than the one in the USA. There are ambitious climate and renewable power targets and performances in progressive states, such as Texas and California, and still, the attractiveness for renewable power investments in the USA is foreseen to continue scattered in the future because of inadequate and steady federal policies.
\end{abstract}

In biofuels employment (1.9 million jobs), Brazil is the leader (41\% of PV Jobs) followed by the USA, Colombia, Indonesia, Thailand, Malaysia, China, and India. In wind employment (1.1 million jobs), China is the leader ( $44 \%$ of PV Jobs) followed by Germany, USA, India, UK, Brazil, Denmark, Netherlands, France, and Spain.

Table 33 shows global renewable energy employment in the corresponding technology branches. As in past years, China maintained the most notable number of people employed (3880 million jobs) estimating for $43 \%$ of the globe's total which is shown in Fig. 8. In India, new solar installations touched a record of $9.6 \mathrm{GW}$ in 2017, efficiently increasing the total installed capacity. The employment in solar PV improved by $36 \%$ and 


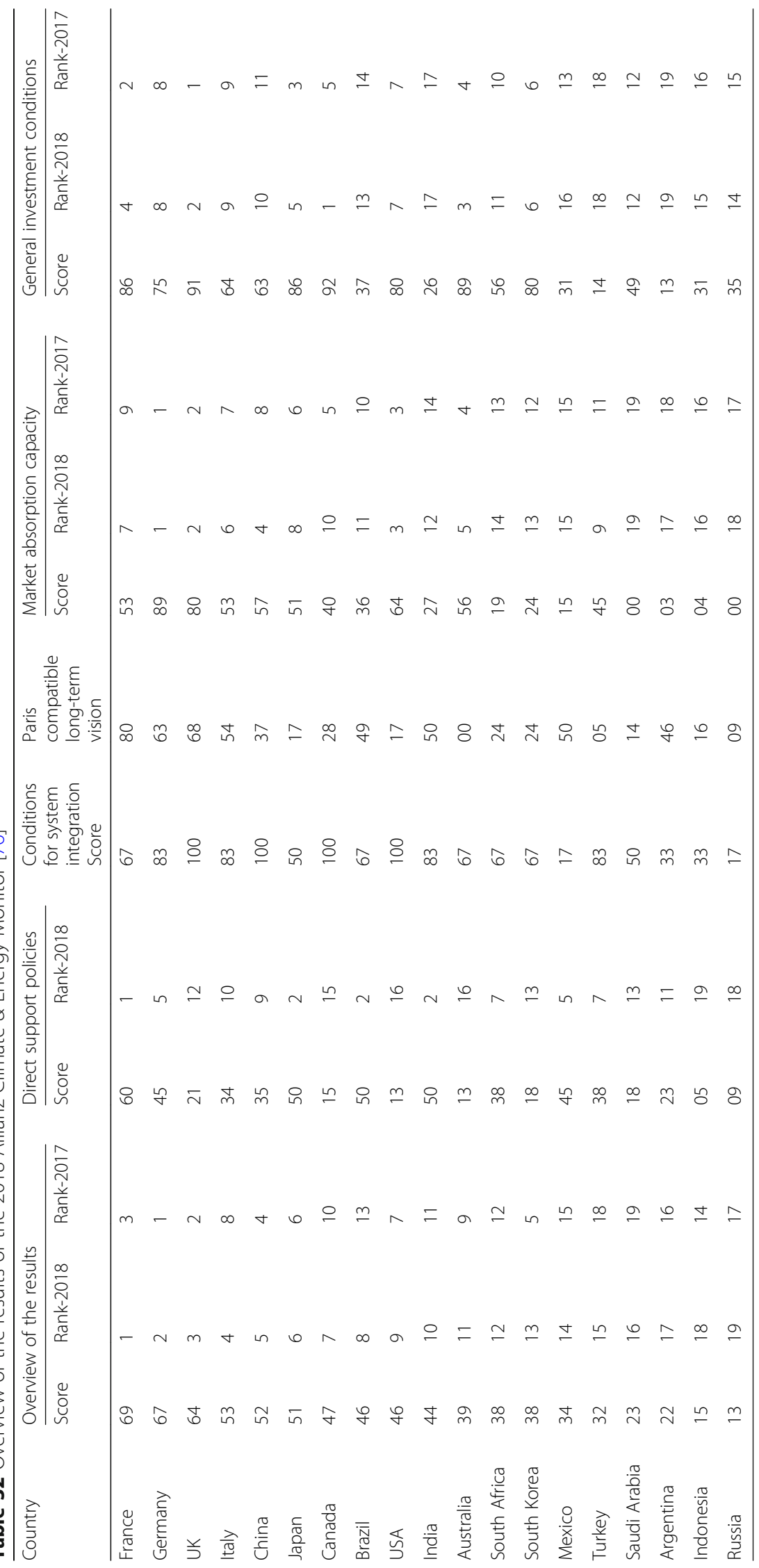


reached 164,400 jobs, of which 92,400 represented on-grid use. IRENA determines that the building and installation covered $46 \%$ of these jobs, with operations and maintenance $(\mathrm{O} \& \mathrm{M})$ representing $35 \%$ and $19 \%$, individually. India does not produce solar PV because it could be imported from China, which is inexpensive. The market share of domestic companies (Indian supplier to renewable projects) declined from $13 \%$ in $2014-2015$ to $7 \%$ in 2017-2018. If India starts the manufacturing base, more citizens will get jobs in the manufacturing field. India had the world's fifth most significant additions of $4.1 \mathrm{GW}$ to wind capacity in 2017 and the fourth largest cumulative capacity in 2018. IRENA predicts that jobs in the wind sector stood at 60,500.

The jobs in renewables are categorized into technological development, installation/de-installation, operation, and maintenance. Tables 34, 35, 36, and 37 show the wind industry, solar energy, biomass, and small hydro-related jobs in project development, component manufacturing, construction, operations, and education, training, and research. As technology quickly evolves, workers in all areas need to update their skills through continuing training/ education or job training, and in several cases could benefit from professional certification. The advantages of moving to renewable energy are evident, and for this reason, the governments are responding positively toward the transformation to clean energy. Renewable energy can be described as the country's next employment boom. Renewable energy job opportunities can transform rural economy $[79,80]$. The renewable energy sector might help to reduce poverty by creating better employment. For example, wind power is looking for specialists in manufacturing, project development, and construction and turbine installation as well as financial services, transportation and logistics, and maintenance and operations.

The government is building more renewable energy power plants that will require a workforce. The increasing investments in the renewable energy sector have the potential to provide more jobs than any other fossil fuel industry. Local businesses and renewable sectors will benefit from this change, as income will increase significantly. Many jobs in this sector will contribute to fixed salaries, healthcare benefits, and skill-building opportunities for unskilled and semi-skilled workers. A range of skilled and unskilled jobs are included in all renewable energy technologies, even though most of the positions in the renewable energy industry demand a skilled workforce. The renewable sector employs semi-skilled and unskilled labor in the construction, operations, and maintenance after proper training. Unskilled labor is employed as truck drivers, guards, cleaning, and maintenance. Semi-skilled labor is used to take regular readings from displays. A lack of consistent data on the potential employment impact of renewables expansion makes it particularly hard to assess the quantity of skilled, semi-skilled, and unskilled personnel that might be needed.

\section{Key findings in renewable energy employment}

The findings comprise (a) that the majority of employment in the renewable sector is contract based, and that employees do not benefit from permanent jobs or security. (b) Continuous work in the industry has the potential to decrease poverty. (c) Most poor citizens encounter obstacles to entry-level training and the employment market due to lack of awareness about the jobs and the requirements. (d) Few renewable programs incorporate developing ownership opportunities for the citizens and the incorporation of women in the sector. (e) The inadequacy of data makes it challenging to build relationships between employment in renewable energy and poverty mitigation.

\section{Recommendations for renewable energy employment}

- When building the capacity, focus on poor people and individuals to empower them with training in operation and maintenance.

- Develop and offer training programs for citizens with minimal education and training, who do not fit current programs, which restrict them from working in renewable areas.

- Include women in the renewable workforce by providing localized training.

- Establish connections between training institutes and renewable power companies to guarantee that (a) trained workers are placed in appropriate positions during and after the

Table 33 Global renewable energy employment for the corresponding technologies in 2012-2017 [79]

\begin{tabular}{lllllll}
\hline Sources (Million Jobs) & 2012 & 2013 & 2014 & 2015 & 2016 & 2017 \\
\hline Solar photovoltaic & 1.36 & 2.27 & 2.5 & 2.77 & 3.09 & 3.37 \\
Bioenergy (biofuel, solid biomass, biogas) & 2.4 & 2.5 & 2.99 & 2.88 & 2.74 & 3.06 \\
Wind energy & 0.75 & 0.83 & 1.03 & 1.08 & 1.16 & 1.15 \\
Solar heating/Cooling & 0.89 & 0.5 & 0.76 & 0.94 & 0.83 & 0.81 \\
Others (Geothermal, SHP, CSP, heat pumps, WTE, Ocean) & 0.33 & 0.38 & 0.4 & 0.4 & 0.45 & 0.45 \\
Total (Million) & 5.73 & 6.48 & 7.68 & 8.07 & 8.27 & 8.84 \\
\hline
\end{tabular}




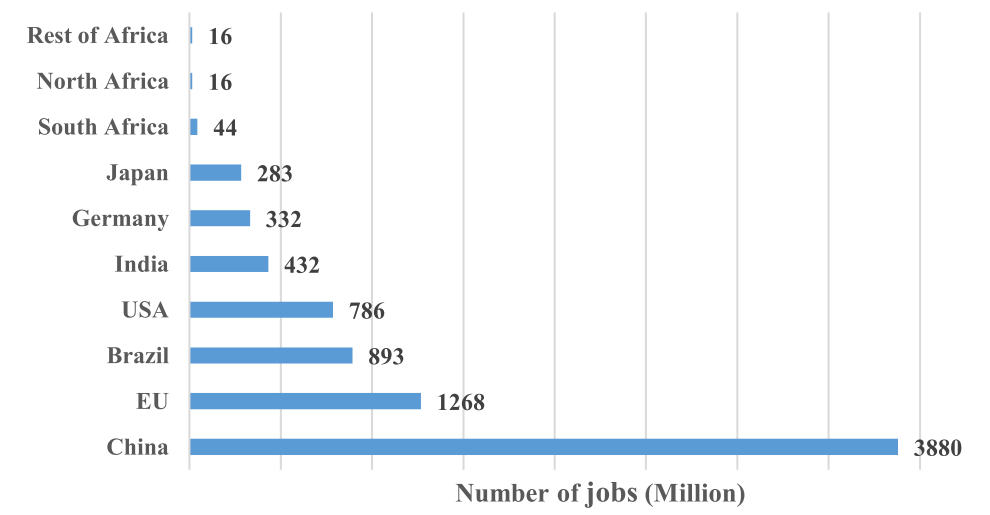

Fig. 8 Renewable energy employment in selected countries [79]

completion of the training program and (b) training programs match the requirements of the renewable sector.

- Poverty impact assessments might be embedded in program design to know how programs motivate poverty reduction, whether and how they influence the community.

- Allow people to have a sense of ownership in renewable projects because this could contribute to the growth of the sector.

- The details of the job being offered (part time, full time, contract-based), the levels of required skills for the job (skilled, semi-skilled and unskilled), the socio-economic status of the employee data need to be collected for further analysis.

- Conduct investigations, assisted by field surveys, to learn about the influence of renewable energy jobs on poverty mitigation and differences in the standard of living.

\section{Challenges faced by renewable energy in India}

The MNRE has been taking dedicated measures for improving the renewable sector, and its efforts have been satisfactory in recognizing various obstacles.

\section{Policy and regulatory obstacles}

- A comprehensive policy statement (regulatory framework) is not available in the renewable sector. When there is a requirement to promote the growth of particular renewable energy technologies, policies might be declared that do not match with the plans for the development of renewable energy.

- The regulatory framework and procedures are different for every state because they define the respective RPOs (Renewable Purchase Obligations) and this creates a higher risk of investments in this sector. Additionally, the policies are applicable for just 5 years, and the generated risk for investments in this sector is apparent. The biomass sector does not have an established framework.

- Incentive accelerated depreciation (AD) is provided to wind developers and is evident in developing India's wind-producing capacity. Wind projects installed more than 10 years ago show that they are not optimally maintained. Many owners of the asset have built with little motivation for tax benefits only. The policy framework does not require the maintenance of the wind projects after the tax advantages have been claimed. There is no control

Table 34 Wind energy job classification based on education levels

\begin{tabular}{ll}
\hline Project development & $\begin{array}{l}\text { Metrological Technician, Land acquisition specialist, Quality Engineer, Civil Engineer, Environmental scientists, } \\
\text { Resource scientists, Regulatory experts, Project Engineer, Power Systems Engineer, financial manager, Power } \\
\text { marketers, Attorneys }\end{array}$ \\
Component manufacturing & $\begin{array}{l}\text { Transportation worker, Trade Worker, Assemblers and fabricators, Salesperson, Logisticians, Buyer, Quality Engineer, } \\
\text { Industrial Engineer, Electrical Engineer, Sales Engineer, Design Engineer, Engineering Manager, Aerospace Engineer, } \\
\text { Research engineer, Attorneys } \\
\text { Construction worker, Trade worker, Construction Manager, Quality Engineer, Electrical Engineer, Mechanical Engineer, } \\
\text { Industrial Engineer, Project Engineer, Project manager }\end{array}$ \\
Operations & $\begin{array}{l}\text { Metrological Technician, Wind technician, Environmental science technician, Site/plant manager, Quality Engineer, } \\
\text { Electrical Engineer, Mechanical Engineer, Asset manager, Attorneys }\end{array}$ \\
Education training & $\begin{array}{l}\text { Technical trainer/instructor, Training and development managers, Analyst and Researcher, Research Engineer, Professor, } \\
\text { and Research }\end{array}$ \\
\hline
\end{tabular}


Table 35 Solar energy job classification based on education level

\begin{tabular}{ll}
\hline Manufacturing & $\begin{array}{l}\text { Computer Numerical control operator, Advanced manufacturing technician, Instrumentation and Electronics technician, } \\
\text { Quality assurance specialist, Process control technician, Electrical Engineer, Industrial Engineer, Environmental Engineer, } \\
\text { Mechanical Engineer, Material Scientists }\end{array}$ \\
System design & $\begin{array}{l}\text { IT Specialist, Residential PV System Designer, Engineering Technician, Utility Interconnection Engineer, Structural Engineer, } \\
\text { Solar Energy Systems Designer, Software Engineer, Power Systems Engineer }\end{array}$ \\
Project development & $\begin{array}{l}\text { Solar Site Assessor, Solar Sales Representative, Solar Marketing Specialist, Building Inspector with Solar Expertise, Electrical } \\
\text { Inspector (Solar Expertise), Code Official with Solar Expertise, Electrical Inspector with Solar Expertise, Code Official with Solar } \\
\text { Expertise, Solar Utility Procurement Specialist, Solar Project Developer, Lawyer with Solar Expertise }\end{array}$ \\
Installation and & Solar Assembler / Basic Installer, Solar Crew Chief, Roofer with Solar Expertise, Plumber with Solar Expertise, Solar Service \\
operations & Technician (residential), Solar PV Installer, HVAC Technician with Solar Expertise, Solar PV Technician (commercial/utility), \\
& Electrician with Solar Expertise, Solar Project Manager, Solar Installation Contractor, Solar Fleet Manager, Solar Instructor \\
\hline
\end{tabular}

over the equipment suppliers because they undertake all wind power plant development activities such as commissioning, operation, and maintenance. Suppliers make the buyers pay a premium and increase the equipment cost, which brings burden to the buyer.

- Furthermore, ready-made projects are sold to buyers. The buyers are susceptible to this trap to save income tax. Foreign investors hesitate to invest because they are exempted from the income tax.

- Every state has different regulatory policy and framework definitions of an RPO. The RPO percentage specified in the regulatory framework for various renewable sources is not precise.

- RPO allows the SERCs and certain private firms to procure only a part of their power demands from renewable sources.

- $\mathrm{RPO}$ is not imposed on open access (OA) and captive consumers in all states except three.

- RPO targets and obligations are not clear, and the RPO compliance cell has just started on 22.05.2018 to collect the monthly reports on compliance and deal with non-compliance issues with appropriate authorities.

- Penalty mechanisms are not specified and only two states in India (Maharashtra and Rajasthan) have some form of penalty mechanisms.

- RPO targets and obligations are not clear, and the RPO compliance cell has just started on 22.05.2018 to collect the monthly reports on compliance and deal with non-compliance issues with appropriate authorities.

- Penalty mechanisms are not specified and only two states in India (Maharashtra and Rajasthan) have some form of penalty mechanisms.

- RPO targets and obligations are not clear, and the RPO compliance cell has just started on 22.05.2018 to collect the monthly reports on compliance and deal with non-compliance issues with appropriate authorities.

- Penalty mechanisms are not specified and only two states in India (Maharashtra and Rajasthan) have some form of penalty mechanisms.

- The parameter to determine the tariff is not transparent in the regulatory framework and many SRECs have established a tariff for limited periods. The FiT is valid for only 5 years, and this affects the bankability of the project.

- Many SERCs have not decided on adopting the CERC tariff that is mentioned in CERCs regulations that deal with terms and conditions for tariff determinations. The SERCs have considered the plant load factor (PLF) because it varies across regions and locations as well as particular technology. The current framework does not fit to these issues.

- Third party sale (TPS) is not allowed because renewable generators are not allowed to sell power to commercial consumers. They have to sell only to industrial consumers. The industrial consumers have a low tariff and commercial consumers have a high tariff, and SRCS

Table 36 Bioenergy job classification based on education levels

\begin{tabular}{ll}
$\begin{array}{l}\text { Equipment manufacture and } \\
\text { distribution }\end{array}$ & R\&D, Design (digesters, refineries, components, etc.), Quality assurance, Marketing and sales, Delivery \\
\hline Project development & $\begin{array}{l}\text { Design, Resource assessment, Environmental and social assessment, Financing, Land agreements, Permitting, } \\
\text { Selection of supplier }\end{array}$ \\
$\begin{array}{ll}\text { Construction and installation } \\
\text { Plant construction, Pre-processing and upgrading, Processing, Quality assurance, Conversion (heat, power, or } \\
\text { fueration and maintenance }\end{array}$ & $\begin{array}{l}\text { Operation and maintenance } \\
\text { biomass Production }\end{array}$ \\
Cross-cutting/enabling activities & $\begin{array}{l}\text { Training, Policymaking, Management \& Administration, Insurance, IT, Health and safety } \\
\text { Financing, Communication, Bio power transmission, and distribution }\end{array}$ \\
\hline
\end{tabular}


Table 37 Small hydropower job classification based on education levels

\begin{tabular}{|c|c|}
\hline $\begin{array}{l}\text { Equipment manufacture and } \\
\text { distribution }\end{array}$ & $\begin{array}{l}\text { R\&D, Design and manufacture: of turbines; generators and excitation; other hydro-mechanical components (e.g., } \\
\text { valves, penstocks); other electrical components (e.g., transformers, power, electronics, etc.); governor and control } \\
\text { systems, Quality, assurance, Marketing and sales, Delivery }\end{array}$ \\
\hline Project development & $\begin{array}{l}\text { Design, Site investigations, and feasibility studies, Environmental and social assessment, Financing Land agreements } \\
\text { Licensing/Permitting, Selection of the supplier }\end{array}$ \\
\hline Construction AND Installation & Project construction, Project commission \\
\hline Operation and maintenance & Routine operation and maintenance, Minor equipment overhauls, Major equipment overhauls \\
\hline Cross-cutting/enabling activities & Training, Policymaking, Management \& Administration, Insurance, IT, Health and safety, Financing \\
\hline
\end{tabular}

do not allow OA. This stops the profit for the developers and investors.

\section{Institutional obstacles}

- Institutes, agencies stakeholders who work under the conditions of the MNRE show poor inter-institutional coordination. The progress in renewable energy development is limited by this lack of cooperation, coordination, and delays. The delay in implementing policies due to poor coordination, decrease the interest of investors to invest in this sector.

- The single window project approval and clearance system is not very useful and not stable because it delays the receiving of clearances for the projects ends in the levy of a penalty on the project developer.

- Pre-feasibility reports prepared by concerned states have some deficiency, and this may affect the small developers, i.e., the local developers, who are willing to execute renewable projects.

- The workforce in institutes, agencies, and ministries is not sufficient in numbers.

- Proper or well-established research centers are not available for the development of renewable infrastructure.

- Customer care centers to guide developers regarding renewable projects are not available.

- Standards and quality control orders have been issued recently in 2018 and 2019 only, and there are insufficient institutions and laboratories to give standards/certification and validate the quality and suitability of using renewable technology.

\section{Financial and fiscal obstacles}

- There are a few budgetary constraints such as fund allocation, and budgets that are not released on time to fulfill the requirement of developing the renewable sector.

- The initial unit capital costs of renewable projects are very high compared to fossil fuels, and this leads to financing challenges and initial burden.

- There are uncertainties related to the assessment of resources, lack of technology awareness, and high- risk perceptions which lead to financial barriers for the developers.

- The subsidies and incentives are not transparent, and the ministry might reconsider subsidies for renewable energy because there was a sharp fall in tariffs in 2018.

- Power purchase agreements (PPA) signed between the power purchaser and power generators on predetermined fixed tariffs are higher than the current bids (Economic survey 2017-2018 and union budget on the 01.02.2019). For example, solar power tariff dropped to 2.44 INR (0. 04 USD) per unit in May 2017, wind power INR 3.46 per unit in February 2017, and 2.64 INR per unit in October 2017.

- Investors feel that there is a risk in the renewable sector as this sector has lower gross returns even though these returns are relatively high within the market standards.

- There are not many developers who are interested in renewable projects. While newly established developers (small and local developers) do not have much of an institutional track record or financial input, which are needed to develop the project (high capital cost). Even moneylenders consider it risky and are not ready to provide funding. Moneylenders look exclusively for contractors who have much experience in construction, well-established suppliers with proven equipment and operators who have more experience.

- If the performance of renewable projects, which show low-performance, faces financial obstacles, they risks the lack of funding of renewable projects.

- Financial institutions such as government banks or private banks do not have much understanding or expertise in renewable energy projects, and this imposes financial barriers to the projects.

- Delay in payment by the SERCs to the developers imposes debt burden on the small and local developers because moneylenders always work with credit enhancement mechanisms or guarantee bonds signed between moneylenders and the developers.

\section{Market obstacles}

- Subsidies are adequately provided to conventional fossil fuels, sending the wrong impression that power from 
conventional fuels is of a higher priority than that from renewables (unfair structure of subsidies)

- There are four renewable markets in India, the government market (providing budgetary support to projects and purchase the output of the project), the government-driven market (provide budgetary support or fiscal incentives to promote renewable energy), the loan market (taking loan to finance renewable based applications), and the cash market (buying renewablebased applications to meet personal energy needs by individuals). There is an inadequacy in promoting the loan market and cash market in India.

- The biomass market is facing a demand-supply gap which results in a continuous and dramatic increase in biomass prices because the biomass supply is unreliable (and, as there is no organized market for fuel), and the price fluctuations are very high. The type of biomass is not the same in all the states of India, and therefore demand and price elasticity is high for biomass.

- Renewable power was calculated based on cost-plus methods (adding direct material cost, direct labor cost, and product overhead cost). This does not include environmental cost and shields the ecological benefits of clean and green energy.

- There is an inadequate evacuation infrastructure and insufficient integration of the grid, which affects the renewable projects. SERCs are not able to use all generated power to meet the needs because of the non-availability of a proper evacuation infrastructure. This has an impact on the project, and the SERCs are forced to buy expensive power from neighbor states to fulfill needs.

- Extending transmission lines is not possible/not economical for small size projects, and the seasonality of generation from such projects affect the market.

- There are few limitations in overall transmission plans, distribution CapEx plans, and distribution licenses for renewable power. Power evacuation infrastructure for renewable energy is not included in the plans.

- Even though there is an increase in capacity for the commercially deployed renewable energy technology, there is no decline in capital cost. This cost of power also remains high. The capital cost quoted by the developers and providers of equipment is too high due to exports of machinery, inadequate built up capacity, and cartelization of equipment suppliers (suppliers join together to control prices and limit competition).

- There is no adequate supply of land, for wind, solar, and solar thermal power plants, which lead to poor capacity addition in many states.

\section{Technological obstacles}

- Every installation of a renewable project contributes to complex risk challenges from environmental uncertainties, natural disasters, planning, equipment failure, and profit loss.

- MNRE issued the standardization of renewable energy projects policy on the 11th of December 2017 (testing, standardization, and certification). They are still at an elementary level as compared to international practices. Quality assurance processes are still under starting conditions. Each success in renewable energy is based on concrete action plans for standards, testing and certification of performance.

- The quality and reliability of manufactured components, imported equipment, and subsystems is essential, and hence quality infrastructure should be established. There is no clear document related to testing laboratories, referral institutes, review mechanism, inspection, and monitoring.

- There are not many R\&D centers for renewables. Methods to reduce the subsidies and invest in $R \& D$ lagging; manufacturing facilities are just replicating the already available technologies. The country is dependent on international suppliers for equipment and technology. Spare parts are not manufactured locally and hence they are scarce.

\section{Awareness, education, and training obstacles}

- There is an unavailability of appropriately skilled human resources in the renewable energy sector. Furthermore, it faces an acute workforce shortage.

- After installation of renewable project/applications by the suppliers, there is no proper follow-up or assistance for the workers in the project to perform maintenance. Likewise, there are not enough trained and skilled persons for demonstrating, training, operation, and maintenance of the plant.

- There is inadequate knowledge in renewables, and no awareness programs are available to the general public. The lack of awareness about the technologies is a significant obstacle in acquiring vast land for constructing the renewable plant. Moreover, people using agriculture lands are not prepared to give their land to construct power plants because most Indians cultivate plants.

- The renewable sector depends on the climate, and this varying climate also imposes less popularity of renewables among the people.

- The per capita income is low, and the people consider that the cost of renewables might be high and they might not be able to use renewables. 
- The storage system increases the cost of renewables, and people believe it too costly and are not ready to use them.

- The environmental benefits of renewable technologies are not clearly understood by the people and negative perceptions are making renewable technologies less prevalent among them.

\section{Environmental obstacles}

- A single wind turbine does not occupy much space, but many turbines are placed five to ten rotor diameters from each other, and this occupies more area, which include roads and transmission lines.

- In the field of offshore wind, the turbines and blades are bigger than onshore wind turbines, and they require a substantial amount of space. Offshore installations affect ocean activities (fishing, sand extraction, gravel extraction, oil extraction, gas extraction, aquaculture, and navigation). Furthermore, they affect fish and other marine wildlife.

- Wind turbines influence wildlife (birds and bats) because of the collisions with them and due to air pressure changes caused by wind turbines and habitat disruption. Making wind turbines motionless during times of low wind can protect birds and bats but is not practiced.

- Sound (aerodynamic, mechanical) and visual impacts are associated with wind turbines. There is poor practice by the wind turbine developers regarding public concerns. Furthermore, there are imperfections in surfaces and sound-absorbent material which decrease the noise from turbines. The shadow flicker effect is not taken as severe environmental impact by the developers.

- Sometimes wind turbine material production, transportation of materials, on-site construction, assembling, operation, maintenance, dismantlement, and decommissioning may be associated with global warming, and there is a lag in this consideration.

- Large utility-scale solar plants require vast lands that increase the risk of land degradation and loss of habitat.

- The PV cell manufacturing process includes hazardous chemicals such as 1-1-1 Trichloroethene, $\mathrm{HCL}, \mathrm{H}_{2} \mathrm{SO}_{4}$, $\mathrm{N}_{2}, \mathrm{NF}$, and acetone. Workers face risks resulting from inhaling silicon dust. The manufacturing wastes are not disposed of properly. Proper precautions during usage of thin-film PV cells, which contain cadmium-telluride, gallium arsenide, and copperindium-gallium-diselenide are missing. These materials create severe public health threats and environmental threats.
- Hydroelectric power turbine blades kill aquatic ecosystems (fish and other organisms). Moreover, algae and other aquatic weeds are not controlled through manual harvesting or by introducing fish that can eat these plants.

\section{Discussion and recommendations based on the research \\ Policy and regulation advancements}

- The MNRE should provide a comprehensive action plan or policy for the promotion of the renewable sector in its regulatory framework for renewables energy. The action plan can be prepared in consultation with SERCs of the country within a fixed timeframe and execution of the policy/action plan.

- The central and state government should include a "Must run status" in their policy and follow it strictly to make use of renewable power.

- A national merit order list for renewable electricity generation will reduce power cost for the consumers. Such a merit order list will help in ranking sources of renewable energy in an ascending order of price and will provide power at a lower cost to each distribution company (DISCOM). The MNRE should include that principle in its framework and ensure that SERCs includes it in their regulatory framework as well.

- SERCs might be allowed to remove policies and regulatory uncertainty surrounding renewable energy. SERCs might be allowed to identify the thrust areas of their renewable energy development.

- There should be strong initiatives from municipality (local level) approvals for renewable energy-based projects.

- Higher market penetration is conceivable only if their suitable codes and standards are adopted and implemented. MNRE should guide minimum performance standards, which incorporate reliability, durability, and performance.

- A well-established renewable energy certificates (REC) policy might contribute to an efficient funding mechanism for renewable energy projects. It is necessary for the government to look at developing the REC ecosystem.

- The regulatory administration around the RPO needs to be upgraded with a more efficient "carrot and stick" mechanism for obligated entities. A regulatory mechanism that both remunerations compliance and penalizes for non-compliance may likely produce better results.

- RECs in India should only be traded on exchange. Over-the-counter (OTC) or off-exchange trading will potentially allow greater participation in the 
market. A REC forward curve will provide further price determination to the market participants.

- The policymakers should look at developing and building the REC market.

- Most states have defined RPO targets. Still, due to the absence of implemented RPO regulations and the inadequacy of penalties when obligations are not satisfied, several of the state DISCOMs are not complying completely with their RPO targets. It is necessary that all states adhere to the RPO targets set by respective SERCs.

- The government should address the issues such as DISCOM financials, must-run status, problems of transmission and evacuation, on-time payments and payment guarantees, and deemed generation benefits.

- Proper incentives should be devised to support utilities to obtain power over and above the RPO mandated by the SERC.

- The tariff orders/FiTs must be consistent and not restricted for a few years.

\section{Transmission requirements}

- The developers are worried that transmission facilities are not keeping pace with the power generation. Bays at the nearest substations are occupied, and transmission lines are already carrying their full capacity. This is due to the lack of coordination between MNRE and the Power Grid Corporation of India (PGCIL) and CEA. Solar Corporation of India (SECI) is holding auctions for both wind and solar projects without making sure that enough evacuation facilities are available. There is an urgent need to make evacuation plans.

- The solution is to develop numerous substations and transmission lines, but the process will take considerably longer time than the currently underconstruction projects take to get finished.

- In 2017-2018, transmission lines were installed under the green energy corridor project by the PGCIL, with 1900 circuit $\mathrm{km}$ targeted in 2018-2019. The implementation of the green energy corridor project explicitly meant to connect renewable energy plants to the national grid. The budget allocation of INR 6 billion for 2018-2019 should be increased to higher values.

- The mismatch between MNRE and PGCIL, which are responsible for inter-state transmission, should be rectified.

- State transmission units (STUs) are responsible for the transmission inside the states, and their fund requirements to cover the evacuation and transmission infrastructure for renewable energy should be fulfilled. Moreover, STUs should be penalized if they fail to fulfill their responsibilities.

- The coordination and consultation between the developers (the nodal agency responsible for the development of renewable energy) and STUs should be healthy.

\section{Financing the renewable sector}

- The government should provide enough budget for the clean energy sector. China's annual budget for renewables is 128 times higher than India's. In 2017, China spent USD 126.6 billion (INR 9 lakh crore) compared to India's USD 10.9 billion (INR 75500 crore). In 2018, budget allocations for grid interactive wind and solar have increased but it is not sufficient to meet the renewable target.

- The government should concentrate on R\&D and provide a surplus fund for R\&D. In 2017, the budget allotted was an INR 445 crore, which was reduced to an INR 272.85 crore in 2016. In 2017-2018, the initial allocation was an INR 144 crore that was reduced to an INR 81 crore during the revised estimates. Even the reduced amounts could not be fully used, there is an urgent demand for regular monitoring of $R \& D$ and the budget allocation.

- The Goods and Service Tax (GST) that was introduced in 2017 worsened the industry performance and has led to an increase in costs and poses a threat to the viability of the ongoing projects, ultimately hampering the target achievement. These GST issues need to be addressed.

- Including the renewable sector as a priority sector would increase the availability of credit and lead to a more substantial participation by commercial banks.

- Mandating the provident funds and insurance companies to invest the fixed percentage of their portfolio into the renewable energy sector.

- Banks should allow an interest rebate on housing loans if the owner is installing renewable applications such as solar lights, solar water heaters, and PV panels in his house. This will encourage people to use renewable energy. Furthermore, income tax rebates also can be given to individuals if they are implementing renewable energy applications.

\section{Improvement in manufacturing/technology}

- The country should move to domestic manufacturing. It imports $90 \%$ of its solar cell and module requirements from Malaysia, China, and Taiwan, so it 
is essential to build a robust domestic manufacturing basis.

- India will provide "safeguard duty" for merely 2 years, and this is not adequate to build a strong manufacturing basis that can compete with the global market. Moreover, safeguard duty would work only if India had a larger existing domestic manufacturing base.

- The government should reconsider the safeguard duty. Many foreign companies desiring to set up joint ventures in India provide only a lukewarm response because the given order in its current form presents inadequate safeguards.

- There are incremental developments in technology at regular periods, which need capital, and the country should discover a way to handle these factors.

- To make use of the vast estimated renewable potential in India, the R\&D capability should be upgraded to solve critical problems in the clean energy sector.

- A comprehensive policy for manufacturing should be established. This would support capital cost reduction and be marketed on a global scale.

- The country should initiate an industry-academia partnership, which might promote innovative $R \& D$ and support leading-edge clean power solutions to protect the globe for future generations.

- Encourage the transfer of ideas between industry, academia, and policymakers from around the world to develop accelerated adoption of renewable power.

\section{Awareness about renewables}

- Social recognition of renewable energy is still not very promising in urban India. Awareness is the crucial factor for the uniform and broad use of renewable energy. Information about renewable technology and their environmental benefits should reach society.

- The government should regularly organize awareness programs throughout the country, especially in villages and remote locations such as the islands.

- The government should open more educational/research organizations, which will help in spreading knowledge of renewable technology in society.

- People should regularly be trained with regard to new techniques that would be beneficial for the community.

- Sufficient agencies should be available to sell renewable products and serve for technical support during installation and maintenance.

- Development of the capabilities of unskilled and semiskilled workers and policy interventions are required related to employment opportunities.
- An increase in the number of qualified/trained personnel might immediately support the process of installations of renewables.

- Renewable energy employers prefer to train employees they recruit because they understand that education institutes fail to give the needed and appropriate skills. The training institutes should rectify this issue. Severe trained human resources shortages should be eliminated.

- Upgrading the ability of the existing workforce and training of new professionals is essential to achieve the renewable goal.

\section{Hybrid utilization of renewables}

- The country should focus on hybrid power projects for an effective use of transmission infrastructure and land.

- India should consider battery storage in hybrid projects, which support optimizing the production and the power at competitive prices as well as a decrease of variability.

- Formulate mandatory standards and regulations for hybrid systems, which are lagging in the newly announced policies (wind-solar hybrid policy on 14.05.2018).

- The hybridization of two or more renewable systems along with the conventional power source battery storage can increase the performance of renewable technologies.

- Issues related to sizing and storage capacity should be considered because they are key to the economic viability of the system.

- Fiscal and financial incentives available for hybrid projects should be increased.

\section{Conclusion}

The renewable sector suffers notable obstacles. Some of them are inherent in every renewable technology; others are the outcome of a skewed regulative structure and marketplace. The absence of comprehensive policies and regulation frameworks prevent the adoption of renewable technologies. The renewable energy market requires explicit policies and legal procedures to enhance the attention of investors. There is a delay in the authorization of private sector projects because of a lack of clear policies. The country should take measures to attract private investors. Inadequate technology and the absence of infrastructure required to establish renewable technologies should be overcome by $R \& D$. The government should allow more funds to support research and innovation activities in this sector. There are insufficiently competent personnel to train, demonstrate, maintain, and operate renewable energy structures and therefore, the institutions should be proactive in preparing the workforce. Imported equipment is costly compared to that of locally 
manufactured; therefore, generation of renewable energy becomes expensive and even unaffordable. Hence, to decrease the cost of renewable products, the country should become involve in the manufacturing of renewable products. Another significant infrastructural obstacle to the development of renewable energy technologies is unreliable connectivity to the grid. As a consequence, many investors lose their faith in renewable energy technologies and are not ready to invest in them for fear of failing. India should work on transmission and evacuation plans.

Inadequate servicing and maintenance of facilities and low reliability in technology decreases customer trust in some renewable energy technologies and hence prevent their selection. Adequate skills to repair/service the spare parts/equipment are required to avoid equipment failures that halt the supply of energy. Awareness of renewable energy among communities should be fostered, and a significant focus on their socio-cultural practices should be considered. Governments should support investments in the expansion of renewable energy to speed up the commercialization of such technologies. The Indian government should declare a well-established fiscal assistance plan, such as the provision of credit, deduction on loans, and tariffs. The government should improve regulations making obligations under power purchase agreements (PPAs) statutorily binding to guarantee that all power DISCOMs have PPAs to cover a hundred percent of their RPO obligation. To accomplish a reliable system, it is strongly suggested that renewables must be used in a hybrid configuration of two or more resources along with conventional source and storage devices. Regulatory authorities should formulate the necessary standards and regulations for hybrid systems. Making investments economically possible with effective policies and tax incentives will result in social benefits above and beyond the economic advantages.

\section{Abbreviations \\ AD: Accelerated depreciation; BU: Billion units; CEA: Central Electricity Authority of India; CERC: Central electricity regulatory commission; CFA: Central financial assistance; EOI: Expression of interest; FDI: Foreign direct investment; FiT: Feed-in-tariff; GW: Giga Watt; MNRE: Ministry of new and renewable energy; MW: Mega Watt; R\&D: Research and development; RPO: Renewable purchase obligations; SERC: State electricity regulatory; SHP: Small hydropower; TWh: Terawatt hours; WTE: Waste to energy}

\section{Acknowledgments}

The authors gratefully acknowledge the support provided by the Research Consultancy Institute (RCI) and the department of Electrical and Computer Engineering of Effat University, Saudi Arabia.

\section{Authors' contributions}

CRK conceptualized the research, undertook fieldwork, analyzed the data, and wrote the manuscript. MAM conceptualized the research, wrote the manuscript, and supervised the research. Both authors have read and approved the final manuscript.

\section{Funding}

Not applicable.
Availability of data and materials

Not applicable.

Ethics approval and consent to participate

Not applicable.

\section{Consent for publication}

Not applicable.

\section{Competing interests}

The authors declared that they have no competing interests.

Received: 15 September 2018 Accepted: 27 November 2019

Published online: 07 January 2020

\section{References}

1. Chr.Von Zabeltitz (1994) Effective use of renewable energies for greenhouse heating. Renewable Energy 5:479-485.

2. Charles Rajesh Kumar. J, Vinod Kumar.D, M.A. Majid (2019) Wind energy programme in India: emerging energy alternatives for sustainable growth. Energy \& Environment 30(7):1135-1189.

3. National electricity plan (2016), Volume 1, Generation, Central Electricity Authority (CEA),Ministry of Power, GOI .Available at http://www.cea.nic.in/ reports/committee/nep/nep_dec.pdf.Accessed 31 Jan 2018.

4. Canadian environmental sustainability indicators (2017), Global greenhouse gas emissions. Available at http://www.ec.gc.ca/indicateurs-indicators/54C061 B5-44F7-4A93-A3EC-5F8B253A7235/GlobalGHGEmissions_EN.pdf. Accessed 27 June.2017.

5. Pappas D (2017) Energy and Industrial Growth in India: The Next Emissions Superpower? Energy procedia 105:3656-3662

6. Agreement P (2015) Available at ttps://unfccc.int/sites/default/files/english_ paris_agreement.pdf.Accessed 20. Aug 2017

7. Aggarwal $P(2017) 2^{\circ} \mathrm{C}$ target, India's climate action plan and urban transport sector. Travel Behavior and Society 6:110-116

8. World Energy Scenarios Composing energy futures to 2050 (2013), World energy Council. https:/www.worldenergy.org/wp-content/uploads/2013/ 09/World-Energy-Scenarios_Composing-energy-futures-to-2050_Full-report. pdf .Accessed 01 Jan 2017.

9. Blondeel M, Van de Graaf T (2018) Toward a global coal mining moratorium? A comparative analysis of coal mining policies in the USA, China, India and Australia. Climatic Change 150(1-2):89-101

10. Kumar S (2016) CO2 emission reduction potential assessment using renewable energy in India. Energy 97:273-282

11. Charles Rajesh Kumar. J, Mary Arunsi. B, Jenova. R, M.A.Majid (2019) Sustainable waste management through waste to energy technologies in India_opportunities and environmental impacts. International journal of renewable energy research 9(1): 309-342.

12. National Institution for Transforming India(2015), Government of India, Report of the Expert group on 175 GW RE by 2022,Available at http://niti. gov.in/writereaddata/files/writereaddata/files/document_publication/ report-175-GW-RE.pdf.Accessed 31 Dec 2016.

13. Sholapurkar RB, Mahajan YS (2015) Review of wind energy development and policy in India. Energy Technology \& Policy 2:122-132

14. India Energy scenarios 2047 (2015), ISGF for planning commission. Available at http://www.indiaenvironmentportal.org.in/files/file/ISGF_IES\%202047\%2 ODocumentation.pdf.Accessed 01 Jan 2017].

15. Harrison T, Kostka G (2014) Balancing priorities, aligning interests: developing mitigation capacity in China and India. Comparative Political Studies 47:450-480

16. Akash KumarShukl (2017) Renewable energy resources in South Asian countries: challenges, policy and recommendations.Resource-Efficient Technologies 3: 342-346.

17. Schmid G (2012) The development of renewable energy power in India: which policies have been effective? Energy Policy 45:317-326

18. Vikas Khare, SavitaNema,PrashantBareda (2013) Status of solar wind renewable energy in India, Renewable and Sustainable Energy Reviews. 27: 1-10

19. Singh R (2015) India's renewable energy targets: How to overcome a \$200 billion funding gap. Renewable Energy Focus. 16(4):60-61

20. T.Blenkinsopp, S.RColes, K.Kirwan (2013) Renewable energy for rural communities in Maharashtra, India, Energy Policy.60:192-199 
21. Kandp TC, Garg HP (1998) Renewable energy education for technicians/ mechanics. Renewable Energy. (14(1-4):393-400

22. Subhes C,Bhattacharyya, Shaping a sustainable energy future for India: management challenges, Energy Policy .38(8):4173-4185

23. Swaran Singh, Boparaik.C.Secretary, India and renewable energy: a future challenge, Renewable Energy.15(1-4): 16-21.

24. Rehman S, Hussain Z (2017) Renewable energy governance in India: challenges and prospects for achieving the 2022 energy goals Journal of Resources, Energy and Development. 14(1):13-22

25. K Kaygusuz, S. BilgenEnergy related environmental policies in Turkey Energy Sources Part B, 3 (2008), pp. 396-410.

26. Y Chang, J Lee, H. Yoon Alternative projection of the world energy consumption-in comparison with the 2010 international energy outlook Energy Policy, 50 (2010), pp. 154-160.

27. Wang W (2014) M Zhang. P. Li Exploring temporal and spatial evolution of global energy production and consumption Renew Sustain Energy Rev 30:943-949

28. BP Energy Outlook country and regional insights-India (2018) https:// www.bp.com/content/dam/bp/en/corporate/pdf/energy-economics/ energy-outlook/bp-energy-outlook-2018-country-insight-india.pdf. Accessed 30 Jun 2018.

29. EIA Energy outlook 2019 with projections to 2050 (2019), Available at https://www.eia.gov/outlooks/aeo/pdf/aeo2019.pdf.

30. International energy outlook 2018 (IEO2018), EIA Energy outlook 2018(2018), Available at https://www.eia.gov/pressroom/presentations/capuano_07242 018.pdf .Accessed 30.07.2018.

31. World meters (2019).Available at http://www.worldometers.info/worldpopulation/india-population.Accessed 24 Jan 2019.

32. Inaki Arto (2016) The energy requirements of a developed world", Energy for Sustainable Development.33: 1-13.

33. Power sector at a glance all India (2019), Ministry of Power, Government of India. Available at https://powermin.nic.in/en/content/power-sector-glanceall-india.Accessed 31 Oct 2018

34. VikasKhare (2013) Status of solar wind renewable energy in India Renewable and Sustainable Energy Reviews.27:1-10.

35. REMAP, renewable energy prospects for India (2017), The International renewable energy agency (IRENA). Available at https://www.irena.org/-/ media/Files/RENA/Agency/Publication/2017/May/RENA_REmap_India_ paper_2017.pdf.Accessed 23 Aug 2017.

36. Draft national electricity plan, Volume 1, Generation, Central Electricity Authority (CEA), Ministry of Power, GOI Report 2016. http://www.cea.nic.in/ reports/committee/nep/nep_dec.pdf.Accessed 26.06.2017.

37. BSK Naidu,Indian scenario of renewable energy for sustainable development, Energy policy ,Vol 24 ,N0 6,pp 575-581,1996.

38. Ashwani Kumar,Kapil Kumar, Naresh Kaushik, Satyawati Sharma,Saroj Mishra, Renewable energy in India:Current status and future potentials, Journal of renewable and sustainable energy reviews, 14(2010),2434-2442

39. Bandyopadhyay S (2017) Renewable targets for India. Clean Technologies and Environmental Policy 19(2):293-294

40. Ministry of New and Renewable Energy (2017),Annual report 201617,Available at http://mnre.gov.in/file-manager/annual-report/2016-2017/EN/ pdf/1.pdf.Accessed 31 April 2017.

41. Nimish Kumar, Nitai Pal, The existence of barriers and proposed recommendations for the development of renewable energy in Indian perspective, Environment, Development and Sustainability,pp1-19.2018.

42. Yearend review (2017), Government of India, Ministry of New and Renewable Energy. Available at https://mnre.gov.in/file-manager/akshayurja/april-2018/Images/44-45.pdf.Accessed 27 Jan 2018.

43. Central Electricity authority of India (2018), Government of India. Available at http://www.cea.nic.in/reports/monthly/executivesummary/2018/exe_ summary-12.pdf.Accessed 31 Jan 2018.

44. The growth of Electricity sector in India from 1947-2017(2017), Central Electricity Authority of India, Government of India. Available at http://www. cea.nic.in/reports/others/planning/pdm/growth_2017.pdf. Accessed 31 June 2017.

45. Renewable energy, Indian brand equity foundation (2018). Available at https://www.ibef.org/download/renewable-energy-dec-2018.pdf.Accessed 05 Jan 2019

46. Prayas energy group (2018) .Available at http://www.prayaspune.org/peg/recapacity.html.Accessed 31 June 2018.

47. Subhojit Dawn, Prashant Kumar Tiwari, Arup Kumar Goswami, Ankit Kumar, Singh Rajesh Panda (2019) Wind power: Existing status, achievements and government's initiative towards renewable power dominating India Energy Strategy Reviews.23:178-199.

48. Generation monthly reports, Central electricity Authority of India (2018) Available at http://www.cea.nic.in/reports/monthly/renewable/2018/ overview-11.pdf. .

49. Ian Partridge (2013) Renewable electricity generation in India_a learning rate analysis Energy Policy.60:906:915.

50. J. Jeslin Drusila Nesamalar, P. Venkatesh, S. Charles Raja (2017) The drive of renewable energy in Tamilnadu: Status, barriers and future prospect Renewable and Sustainable Energy Reviews.73:115-124.

51. A Report on Energy Efficiency and Energy Mix in the Indian Energy System (2030) Using India Energy Security Scenarios 2047 (2017), Available at http:// niti.gov.in/writereaddata/files/document_publication/Energy_Efficiency.pdf. Accessed 06 April 2017.

52. Initiatives and achievements, MNRE (2018).Available at https://mnre.gov.in/ sites/default/files/uploads/MNRE-4-Year-Achievement-Booklet.pdf.

53. Acheievements of ministry of new and renewable energy during 2018. (2019). Available at https:/pibindia.wordpress.com/2018/12/11/achievements-ofministry-of-new-renewable-energy-during-2018/.Accessed 09 Jan 2019.

54. Standing committee on energy (2017-18), sixteenth lok sabha, MNRE, demands for grands (2018-19), 39th (2018). Available at http://164.100.47.1 93/Isscommittee/Energy/16_Energy_39.pdf.

55. Mukesh KumarMishra, NilayKhare,Alka BaniAgrawa (2015) Small hydro power in India: Current status and future perspectives Renewable and Sustainable Energy Reviews.51:101-115.

56. Tara Chandra Kandpal, Bharati Joshi, Chandra ShekharSinha (1991) Economics of family sized biogas plants in India Energy Conversion and Management.32:101-113.

57. Sravanthi Choragudi (2013) Off-grid solar lighting systems: a way align India's sustainable and inclusive development goals Renewable and Sustainable Energy Reviews.28:890-899.

58. Abhigyan Singh,Alex T.Stratin,N.A.Romero Herrera,Debotosh Mahato,David V.Keyson,Hylke W.van Dijk (2018) Exploring peer-to-peer returns in off-grid renewable energy systems in rural India: an anthropological perspective on local energy sharing and trading Energy Research \& Social Science.46:194-213.

59. Draft Technology Development and Innovation Policy (TDIP) for New \&Renewable Energy, MNRE (2017). Available at https://mnre.gov.in/filemanager/UserFiles/Draft-TDIP_RE.pdf .Accessed 31 Jan 2018.

60. Demands for grants (2018-19), MNRE, Standing committee on energy, $16^{\text {th }}$ lok sabha, 39th Report (2018). Available at http://164.100.47.193/ Isscommittee/Energy/16_Energy_39.pdf.Accessed 31 Oct 2018.

61. Mohit Goyal (2010) Repowering - next big thing in India Renewable and Sustainable Energy Reviews.1 4(5):1400-1409.

62. B.N.Prashanth,R.Pramod,G.B. VeereshKumar (2018) Design and development of hybrid wind and solar energy system for power generation. 5(5):11415-11422.

63. Swaminathan mani,Tarun Dhingra (2013) Policies to accelerate the growth of offshore wind energy sector in India Renewable and Sustainable Energy Reviews.24: 473-482

64. Draft amendments to tariff policy, MNRE (2018). Available at https:// powermin.nic.in/sites/default/files/webform/notices/Proposed_ amendments_in_Tariff_Policy_0.pdf. .

65. T.C.Kandpal, H.P.Garg (1998) Renewable energy education for technicians/ mechanics Renewable Energy. Volume 14(1-4): 393-400.

66. T.Blenkinsopp, S.RColes K.Kirwan (2013) Renewable energy for rural communities in Maharashtra, India Energy policy.60:192-199.

67. Renewable Energy Country Attractiveness Index (RECAI) (2018), Available at https:/www.ey.com/Publication/vwLUAssets/ey-recai-issue-52-index-scores/ \$File/ey-recai-issue-52-index-scores.pdf. .

68. Renewables 2018, global status report, Renewable energy policy network for the $21^{1 \text { st }}$ century (REN21) (2018). Available at http://www. ren21.net/wp-content/uploads/2018/06/17-8652_GSR2018_FullReport_ web_final_.pdf.

69. Clean Energy Investment trends, 2Q 2018, BloombergNEF (2018).Available at https://data.bloomberglp.com/bnef/sites/14/2018/07/BNEF-Clean-EnergyInvestment-Trends-1H-2018.pdf.Accessed 12 Dec 2018.

70. Rolf Wüstenhagen, Emanuela Menichetti (2012) Strategic choices for renewable energy investment: conceptual framework and opportunities for further research Energy Policy.40:1-10.

71. Longayanxia dam solar park, earth observatory (NASA) (2017). Available at https://earthobservatory.nasa.gov/images/89668/longyangxia-dam-solar-park. . 
72. Dawn, Subhojit Dawn, Prashant Kumar Tiwari,Arup Kumar Goswami, Manash Kumar Mishra. (2016).Recent developments of solar energy in India: perspectives, strategies and future goals. Renewable and Sustainable Energy Reviews.62:215-235.

73. Press information Bureau, MNRE FDI in renewable energy sector (2018). Available at http://pib.nic.in/newsite/PrintRelease.aspx?relid=186849. Accessed 01 Feb 2019.

74. Renewable energy, India brand equity foundation, Report August 2018. https://www.ibef.org/download/Renewable-Energy-Report-August-2018.pdf. Accessed 31.12.2018.

75. Global trends in renewable energy investment 2018, Bloomberg new energy (2018).Available at http://www.iberglobal.com/files/2018/renewable_trends.pdf.

76. Deep dive -Allianz climate and energy monitor (2017).Available at https:// newclimate.org/wp-content/uploads/2017/04/allianz-climate-and-energymonitor-deep-dive-2017.pdf.

77. Allianz climate and energy monitor (2018), Available at https:/www.allianz. com/content/dam/onemarketing/azcom/Allianz_com/sustainability/ documents/Allianz_Climate_and_Energy_Monitor_2018.pdf. .

78. Renewable energy and Jobs -Annual review 2018 (2018). Available at https://irena.org///media/Files/RENA/Agency/Publication/2018/May/RENA_ RE_Jobs_Annual_Review_2018.pdf.Accessed Jan 2019.

79. A. Bergmann, N. Hanley, R. Wright Valuing the attributes of renewable energy investments. Energy Policy, 34 (9) (2006), pp. 1004-1014

80. József Benedek, Tihamér-Tibor Sebestyén, BlankaBartók (2018) Evaluation of renewable energy sources in peripheral areas and renewable energy-based rural development Renewable and Sustainable Energy Reviews.90:516-535.

\section{Publisher's Note}

Springer Nature remains neutral with regard to jurisdictional claims in published maps and institutional affiliations.

Ready to submit your research? Choose BMC and benefit from:

- fast, convenient online submission

- thorough peer review by experienced researchers in your field

- rapid publication on acceptance

- support for research data, including large and complex data types

- gold Open Access which fosters wider collaboration and increased citations

- maximum visibility for your research: over $100 \mathrm{M}$ website views per year

At $\mathrm{BMC}$, research is always in progress.

Learn more biomedcentral.com/submissions 